\title{
Adventures, hardship and a scientific legacy: Ludwig Leichhardt's 1843 journey to Mt Royal in the Hunter Valley, NSW
}

\author{
Martin Fallding and Doug Benson ${ }^{1}$ \\ Land \& Environment Planning, Singleton, NSW AUSTRALIA; ${ }^{1}$ The Royal Botanic Gardens and Domain Trust, \\ Royal Botanic Garden, Mrs Macquaries Rd Sydney NSW 2000 AUSTRALIA
}

\begin{abstract}
In January 1843, curiosity for natural history led a young German naturalist, Ludwig Leichhardt, to spend about three weeks exploring Mt Royal on the north of the Hunter Valley, about $70 \mathrm{~km}$ north west of Newcastle, New South Wales. This was a sidetrack on his journey from Newcastle, through the Hunter Valley and inland to Moreton Bay (Brisbane) and preceded the journeys for which he was to become famous; his 1844-45 overland journey from Moreton Bay to Port Essington (in Northern Territory) and his disappearance without trace in 1848 attempting to cross Australia.

Using his Diary and herbarium records this paper brings together the chronological events of the 29 year old Leichhardt's journey, the plant and animal species recorded, the specimens collected and his landscape descriptions and compares the 1843 landscape with the area today. Most of it is now in Mount Royal National Park, and part of the Gondwana Rainforest Reserves World Heritage Area. Using Mt Royal as an example of the richness of Leichhardt's scientific legacy, we draw attention to the existence of a considerable number of Leichhardt's plant specimens in herbaria in Sydney and Melbourne relating to his early collecting around Sydney and the little-known journey from Newcastle to Moreton Bay.

Leichhardt's visit to Mt Royal provides an insight into a gifted young naturalist coping with some of the hardships of nineteenth century botanical exploration, in a landscape which is easily recognizable and of which much is remarkably little changed since European settlement.
\end{abstract}

Cunninghamia (2013) 13: 305-330

doi: 10.7751cunninghamia2013.008

\section{Introduction}

Ludwig Leichhardt is one of nineteenth century Australia's iconic bushman explorers; famous for his 1845 overland expedition from Moreton Bay to Port Essington, and subsequent disappearance attempting to cross the continent. Myths have arisen around a man whose chief aim was to make a significant contribution to science, and whose scientific work was highly regarded by his contemporaries. "Geologists and botanists valued Leichhardt's collections of specimens and the records of his observations which, in an age accustomed to extravagant travellers' tales, were remarkable for their restraint and accuracy; he believed that as long as the traveller was truthful the scientist at home would be thankful to him. Leichhardt was a most dedicated servant of science and from this very dedication sprang a singleness of purpose which shaped his life, and made him somewhat ruthlessly regardless of all but his research. With perseverance, energy, courage and complete disregard of discomfort, and of the physical handicap of poor eyesight, he pursued his goals as 'an explorer of nature'" (Erdos 1967). 
Leichhardt arrived in Sydney in February 1842 and, with his new friend Lieutenant Robert Lynd, with whom he planned to produce a book on the flora of Sydney, began plant collecting around Sydney. On an excursion to the Botany Marshes in May 1842 he collected Symphionema paludosum (LL148) and Corybas fimbriatus, his earliest surviving Australian plant collections (Fensham et al. 2006).

He sailed to Newcastle beginning his first and relatively littleknown journey, up into the Hunter Valley, then north to New England and on to Moreton Bay (now Brisbane). Unlike his later expeditions this was mostly through established grazing properties; he travelled alone, on horseback or on foot. Between September 1842 and March 1843 he spent about six months in the Hunter region. In Newcastle he stayed with businessman Alexander Walker Scott at Ash Island in the Hunter River estuary. Scott was interested in butterflies, and father of the natural history illustrators Helena and Harriet Scott. At the time of Leichhardt's visit, the Scott sisters were about 10 and 11 years old; only three years later they started their paintings to illustrate Australian Lepidoptera (Scott 1864), the first book on Australian butterflies. Scott's manuscript for Lepidoptera notes that "the caterpillar of (Ptilocephala leichhardtii) was first presented to us by Dr Ludwig Leichhardt, in November, 1842, at which time we were much engaged together in the pursuit of Natural History, his attention however being principally directed towards the Botanical riches of the Colony ....".

From Ash Island, Leichhardt rode to Glendon, a large property (about 80,000 acres grazing cattle and sheep) on the Hunter River about $10 \mathrm{~km}$ east of Singleton owned by Helenus Scott, brother of AW Scott, where he stayed as a guest. From here he was to spend about three weeks exploring the Mt Royal area to the northeast. Most of this area is now in Mount Royal National Park, and partly within the Gondwana Rainforest Reserves World Heritage Area. What prompted the visit to Mt Royal remains uncertain but in a letter written at Glendon on 16 January 1843 he wrote to Robert Lynd, "I am again as I was from the first moment I saw the blue distant hills, continually striving to get to them and over them ..... At present, these new mountains are before me, the Wollombi Range, Dyrinne [Mt Dyrring] and Mt Royal. I visited the Paterson and Allan River and they carried such a quantity of basaltic pebbles, that I hope to find at Mt Royal a good lump of basalt." (Aurousseau 1968 p626).

At Mount Royal his enthusiasm for collecting rainforest plants (as specimens for colleagues and material for future publications) and his careful observations of the landscape and geology coincided to produce a valuable record of the landscape at that time, and an intriguing story filled with the pitfalls and perils of nineteenth century scientific collecting. Writing to Walker Scott on 15 February 1843, he described how he had "lived a hermits life for about 3 weeks at Mt Royal, the geology of which as well as the brush of its easterly flancs yielded me a rich harvest of interesting objects. ..... I was between the horns of a wild bull, I was almost burnt to death in a hollow tree - so I hope to become seasoned for the interior." (Aurousseau 1968 p627)
Our project aimed to compile the story of Ludwig Leichhardt's three weeks at Mt Royal, to locate his likely routes, and to integrate his written observations with information from his plant specimens (which have not been previously looked at in an environmental context). The story provides a picture of the young Leichhardt as an active scientist and important information about the past and present landscape in particular locations visited by Leichhardt.

\section{Ludwig Leichhardt (1813-1848?)}

Friedrich Wilhelm Ludwig Leichhardt was born in Germany in October 1813 and developed an interest in natural history while studying at university in Germany and later in England. In October 1841 he sailed for Australia with the expressed intention of exploring Australia's inland (Erdos 1967). His overland journey from Newcastle to Moreton Bay in 1843 was followed by a return to Sydney to arrange his collections of plant and rock specimens and to work on the notes of his observations.

He sailed from Sydney in 1844 to lead an expedition from Moreton Bay to Port Essington; he completed the overland journey of some 4,800 km in December 1845, and subsequently planned a further expedition to cross Australia from Moreton Bay to the west coast. After difficulties and delays, this journey commenced in February 1848 but the expedition disappeared without trace later that year.

Leichhardt left many records of his observations in Australia in his diaries, letters, notebooks, sketch-books, maps, and published works. Recent biographies of Leichhardt include Bailey (2011) and Finger (2013); his story has also been variously interpreted in literary works expressing widely differing views about his achievements, character and contributions.

\section{Methods}

Mt Royal (lat $32^{\circ} 10^{\prime} \mathrm{S}$, long $151^{\circ} 20^{\prime} \mathrm{E}$ ) is at the southern end of the Mt Royal Range on the north side of the Hunter Valley about $70 \mathrm{~km}$ north west of Newcastle. All references to localities, landscape features, and plant species in the Leichhardt material in the Mitchell Library (State Library of NSW) in Sydney covering the time he spent in the Mt Royal area in 1843 were collated. These included Leichhardt's Diary, written in English and German, notebooks written in English, French and German and his published letters (Aurousseau 1968), his description of the geology of Mt Royal published in Germany (Leichhardt 1855) and translated from German by the senior author, and a transcription and translation of German text in his Diary for the period January to March 1843 (Darragh \& Fensham 2013).

Database records of herbarium specimens collected by Leichhardt in the Mt Royal area were sought from state herbaria in Sydney and Melbourne. In the National Herbarium of NSW (coded NSW) database were records of 22 plant specimens; 17 were located in the collection and 
photographed. Leichhardt's handwritten labels on some of the specimens provided further information on their original collecting site. Details from another 40 specimen records were obtained from the National Herbarium of Victoria (coded MEL) database in Melbourne.

To identify his collecting locations in the field and compare his landscape descriptions with the currently existing vegetation it was important to identify his routes. Because events are often referred to out of sequence in the Diary, and separately referred to in a number of letters, compiling the chronology of events was a challenge. The senior author's local knowledge of the Mt Royal area allowed him to identify particular localities, and site visits were undertaken to check the text references and confirm the likely chronology. Additional material used included maps from the time of Leichhardt's visit, early parish and portion maps showing survey descriptions, and the earliest available aerial photographs (from 1939) of the area.

To check place names and review references that might provide relevant information, discussions were held with members of Singleton Historical Society and others. Contemporary information includes vegetation descriptions and maps prepared by the Forestry Commission of NSW and the NSW National Parks \& Wildlife Service Plan of Management for Mt Royal National Park.

The average annual rainfall at Mt Royal is around $1400 \mathrm{~mm}$ but is highly variable due to local topographic variation (Bridgman 1984). During summer, south easterly winds are common and bring moist air and low cloud from the coast and influences the distribution of vegetation with open Eucalypt forests on the drier western slopes and rainforests found in gullies and slopes having a south to easterly aspect.

The weather conditions significantly influenced Leichhardt's activities and as frequently reported in his Diary affected his movements, the plants that were observed, and the conditions under which his plant collecting and drying occurred. Weather records published in the Maitland Mercury and Sydney Morning Herald for January-February 1843 were extracted using weekly weather reports from the towns of Maitland, Singleton, Wollombi and Scone, relatively close to Mt Royal, and compared with the daily Sydney reports to indicate the regional conditions (Appendix 2). Weather observations in the Diary and contemporary newspaper reports for Sydney and the Hunter Valley show general consistency and were compiled to provide context for interpreting Leichhardt's descriptions of particular events.

The Mt Royal excursion was a side trip for Leichhardt, away from the Hunter River where by 1843 most of the pastoral settlement had occurred and where Patricks Plains (now the town of Singleton) had been settled by Europeans 20 years earlier. Contemporary events according to the Maitland Mercury newspaper, which had commenced publication a short time before Leichhardt's visit, included periodic bushranging on the road to Singleton, bands of roaming Aboriginal groups, the highly important agricultural and commodity prices, and commercial and political happenings.

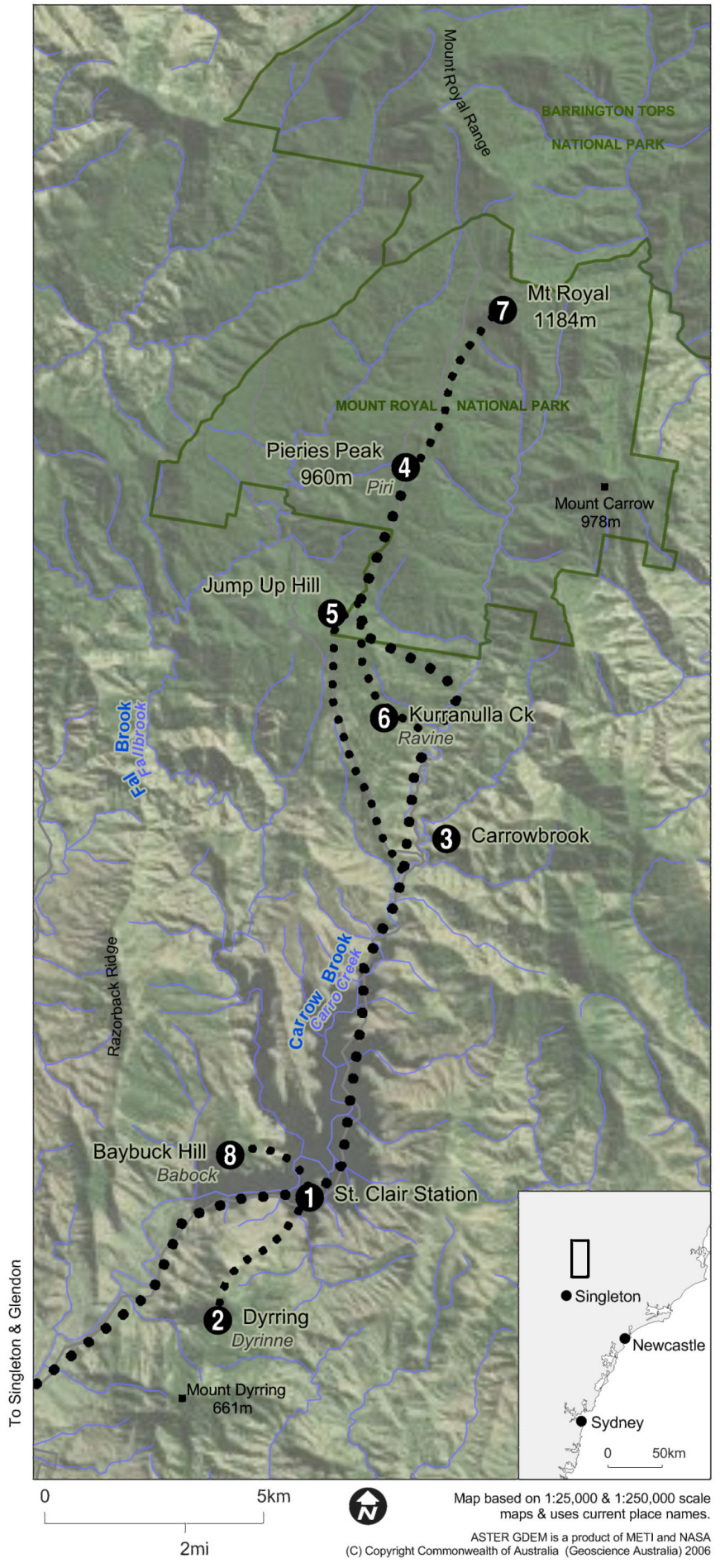

Fig. 1. Mt Royal locality map showing current location names, terrain, Leichhardt's likely routes and current vegetation cover. Names referred to by Leichhardt are shown in italics after current names. Route numbers correspond with known locations and are in chronological order. Leichhardts camp was located a short distance south of location 4, the sawyers hut was between locations 4 and 5 , and Glennies Stockyard is south of location 3. 
Table 1 Current and past place names in the Mt Royal area mentioned by Leichhardt

Leichhardt is likely to have had access to Thomas Mitchell's 1834 map of the colony (Mitchell 1834) which named some of the geographical features at Mt Royal. Leichardt's Diary appears to be the first documentation of some place names such as Piri and Jump Up Hill, many of which are likely to have their origin from the Wonaruah Aboriginal people.

\section{Current name Past names}

Mount Dyrring Dyrinne, Deren, Dyring

Carrow Brook Carro Creek, Carrocreek, Busby's Creek

Pieries Peak Piri

Mount Royal

Fal Brook

Baybuck Hill

Mt Carrow

No name
Fallbrook

Babock, Bibock, Babuck, Bubock, Bebock

Carrow

Jump Up Hill

\section{Comments}

Named and identified in Mitchell's map, possibly in incorrect location

Noted on Mitchell's map

Named and identified in Mitchell's map

Noted on Mitchell's map

Named and identified in Mitchell's map

Northern ridge is named as Jump Spur

\section{Results}

Likely routes used by Leichhardt are shown in Figure 1; Table 1 shows a comparison of some of his place names.

\section{Leichhardt's time at Mt Royal}

Following his stay near Newcastle, Leichhardt travelled to Glendon near Singleton which he used as a base for his Mt Royal explorations. He arrived at Glendon on 20 December 1842 where he spent time observing the wildlife and geology. He refers to native animals seen at Glendon, including possums, native cats, kangaroo rat and kangaroo and familiarised himself with the grassland plants in the Eucalypt woodland. His explorations included a dramatic attack by a bull, in which he lost his geological hammer and escaped shaken and trembling, but otherwise unscathed.

In the weeks leading up to his arrival at Glendon, the countryside had been dry with few streams flowing. In a letter to his brother-in-law on 16 January 1843, Leichhardt observed that "The drought has persisted for an extraordinary time, and there was scarcely enough grass on the vaunted banks of Hunter's River to provide my horse with scanty meals." (Aurousseau 1968 p618)

In reporting the previous week's weather from Wollombi, the Maitland Mercury (of 21 January 1843) observed "On some days a heavy, lowering sky raised hopes, only to be disappointed, of an immediate and heavy fall of rain; this has been followed quickly by a scorching heat, that has as rapidly changed in a few hours to cool, bracing weather. This variable temperature has had a very trying effect upon the health of delicate persons, and the vegetation begins to wear a sickly appearance for wont of rain." It was through a hot, harsh and barren landscape that Leichhardt made his journey to the lush rainforest at Mt Royal.

\section{St Clair, January 1843}

On 24 January 1843, on a dry slightly cloudy day with east to south-easterly breezes, Leichhardt rode to St Clair homestead (now flooded by the Lake St Clair dam), a journey of some $32 \mathrm{~km}$ (20 miles) across what would then have been a dry open Eucalypt woodland landscape with an occasional herd of sheep or cattle accompanied by a shepherd. His journey was in the company of an old sawyer "who had cut timber for more than nine years in the brushes of Mt Royal". (Aurousseau 1968 p630)

As he travelled north, there would have been tantalizing glimpses of the high mountains to the north; he would have followed a regularly travelled track with Fal Brook (also known as Glennies Creek) to the west and the high forested ridges of Mount Dyrring on the east. The hills narrowed near the present Lake St Clair dam wall, before the valley widened at St Clair homestead, where Carrow and Fal Brooks join, the sandstone and conglomerate cliffs of Baybuck Hill overlooked the valley providing a dramatic sense of entrance. The journey to St Clair was not without incident. His horse fell with Leichhardt "violently shaken but broke fortunately no bone". (Aurousseau 1968 p633)

St Clair station was owned by an absentee owner Thomas Steele. Captain Mayne the overseer was not at home when Leichhardt arrived, describing himself as a "stranger slung around with collecting canisters and boxes." (Darragh \& Fensham 2013 p137) but with his letter of introduction he was made welcome. The following day the south easterly winds continued, more than likely bringing pleasant slightly cloudy weather and he climbed Mt Dyrring [Dyrrine] to the south overlooking the valley and St Clair. This would have provided him with the opportunity to familiarise himself with the mountains to the north. He enjoyed a very beautiful view from the peak, writing "You see a large number of strange mountain ranges, which I have tried in part to draw." Darragh \& Fensham (p138) and his Diary includes a sketch of the mountains, mostly correctly named. (See Figures 2A, $2 \mathrm{~B}$ and $2 \mathrm{C}$ ).

\section{Excursion to Mount Royal}

The next day (Thursday 26 January 1843), the journey to the mountains commenced; with south easterly winds again 


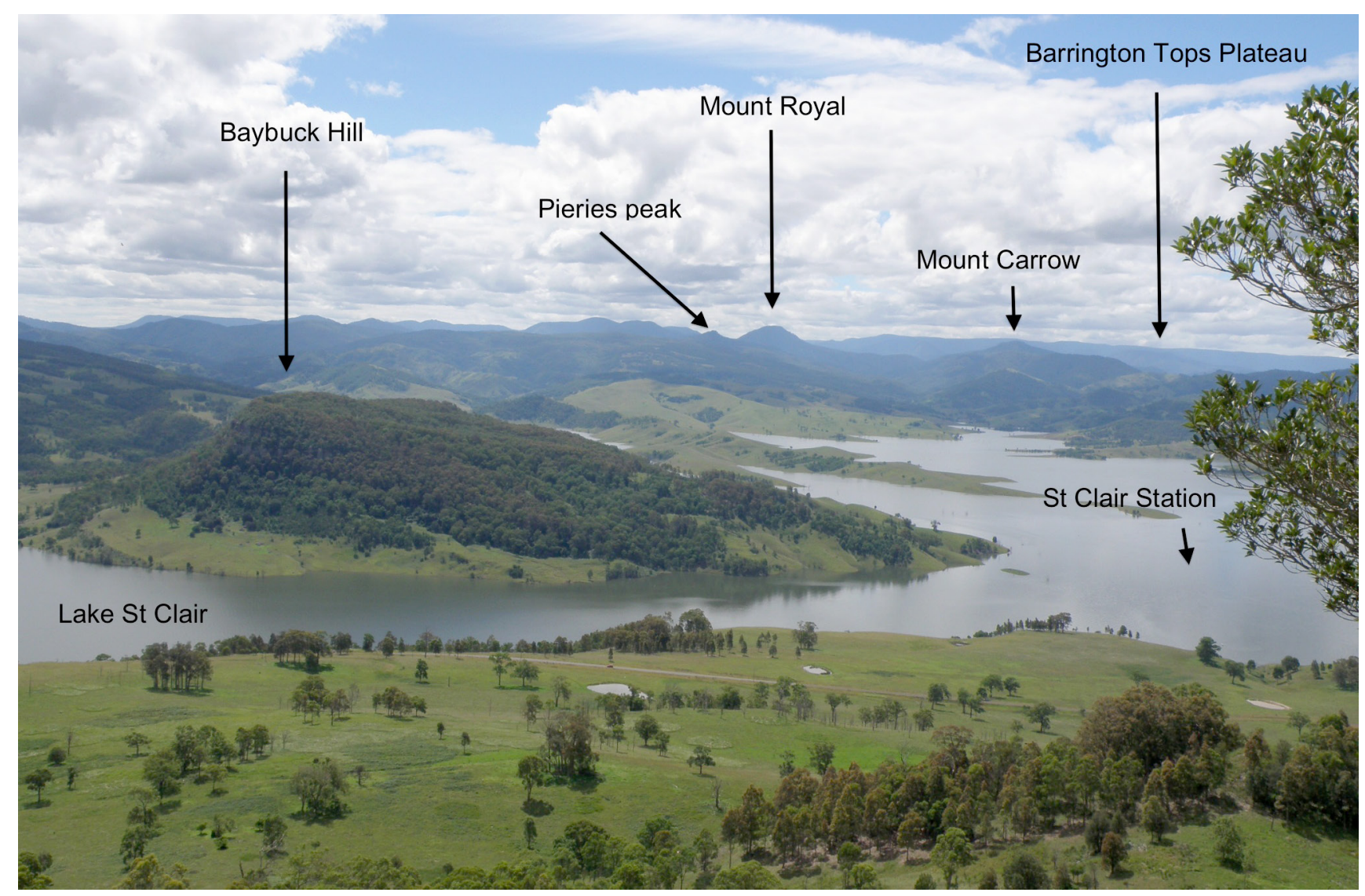

Fig. 2A. View north from northern ridge of Mt Dyrring to Baybuck and Mt Royal

blowing from the coast. The weather report from Wollombi that week noted that "There was every appearance of rain in the early part of the week, but none has yet fallen; the verdue consequently looks sickly, and the late maize shows signs of premature forwardness." (Maitland Mercury, 29 January 1843) On horseback, accompanied by his dog, Leichhardt followed a track used by the sawyers to access the forests of Mt Royal. No mention is made of whether the sawyer was with him, but it is probably unlikely as Leichhardt spent much time making geological observations. The track to Mt Royal would have been quite obvious skirting east of Carrow Brook at the base of high tree covered ridges to the east and south. Leichhardt describes the grassland of the valley, which gave way to rainforests along the creek as the valley narrowed, providing a picture of the transition from open grassland country grazed by domestic animals into the forests and rainforest brushes along the creek, and the steep climb up the ridges to the foot of Pieries Peak [Piri]. "Small

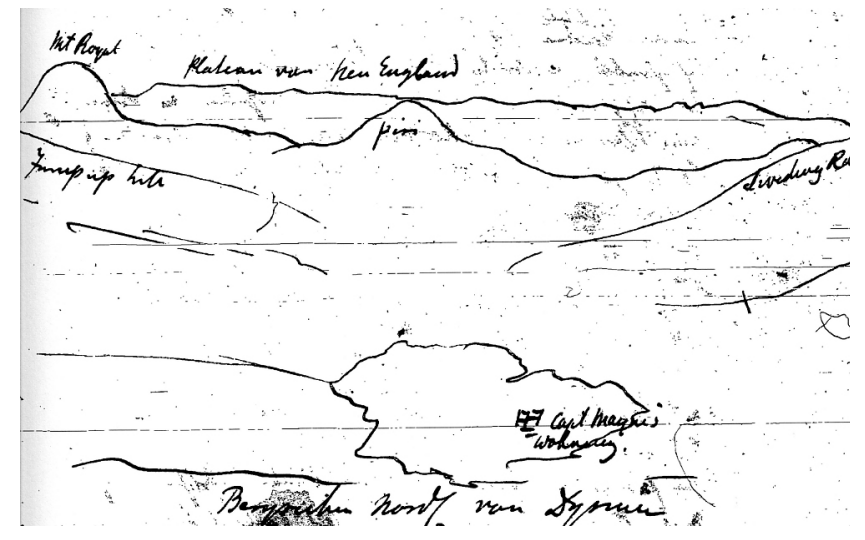

Fig. 2B. Leichhardt's sketch of mountains from Mt Dyrring (from Diary page 65)

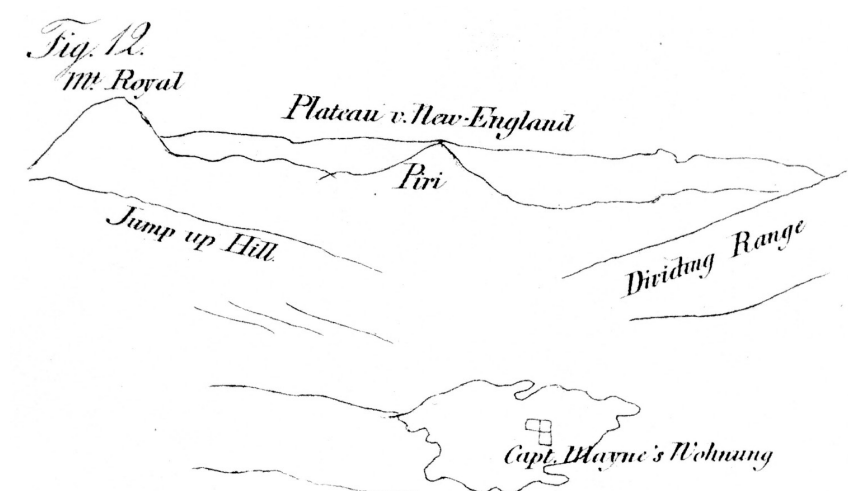

Bergreithen nordlich i: Derith.

Fig. 2C. Sketch reproduced from Diary in Leichhardt (1855) as Figure 12 
grassy paddocks in which the silvertail especially and the red feathery oats were growing. Poa was abundant too. On the stream, Casuarina gives a pleasant dense shade whilst rare ironbark, box and apple tree on the paddocks only provide moderate protection against the hot sun. Higher up, however, these paddocks discontinue after the upper ones had manifested many more ferns between the grass bushes and dense scrub (brush) formed by various rare trees took their place. Here the nettle tree with its broad ventricose leaves, heart-shaped at the base appeared for the first time, which is to be avoided so carefully because of its painful stinging." (Darragh \& Fensham 2013 p140) (see Table 2 for species). Today this landscape is cleared pasture with much of the lower-lying land under the water of Lake St Clair.

Leichhardt appears to have been captivated by the rainforest along upper Carrow Brook and its tributary gullies and by the new plant species and their growth habits he was observing; "The creepers became very numerous, the native vine stretched from trunk to trunk and made the scrub almost impenetrable. Mosses hung down in long garlands from the branches, lichens covered rocks and living and dead plants." (Darragh \& Fensham 2013 p142) He noted fossils along the creek.

After consuming a meal of roasted Potoroo (possibly Longnosed Potoroo - Potorous tridactylus) at the foot of the mountain, he followed the path which left the rainforested valley and its meandering creek, up a sledge track on which bullocks pulled cut timber down. The path to Pieries Peak [Piri] climbed for more than two miles $(3.2 \mathrm{~km})$ up an "extremely steep hillock". He noted "We gained one terrace after the other, always sandstone covered by forest." (Darragh \& Fensham 2013 p142)

Leichhardt refers to the distance from St Clair to Pieries Peak [Piri] as 14 miles $(22 \mathrm{~km})$, (and about 34 miles $(54 \mathrm{~km})$ from Glendon), and must have taken about half a day. He stopped at the base of a steep grassy ridge at the foot of Pieries Peak to camp, but not long afterwards his horse broke its bridle and ran off along the track it had come, probably taking his provisions with it. In search of his horse, Leichhardt returned to Carrow Brook valley along a ridge to Jump Up Hill, used by the sawyers and apparently named by them because of its steep northern ridge. Leichhardt refers to making the "tiring valley and mountain path a second time", returning to his Piri camp without finding his horse, after a round trip of about 8 miles (13 km). (Darragh \& Fensham 2013 p144)

\section{Camp at Pieries Peak [Piri]}

In a grassy tall eucalypt forest almost certainly at the southern end of Pieries Peak, Leichhardt established a camp "in a hollow black butt tree", with the dense brush on the east of the mountain only a short distance away. The much higher peak of Mt Royal is about $3.2 \mathrm{~km}$ ( 2 miles) further north along the ridge separating Carrow Brook and Fal Brook. Occasional hollow trees similar to the one Leichhardt describes he camped in still occur in the area; a dead Eucalyptus obliqua tree near Pieries Peak measured 8.6 metres d.b.h. and could easily have accommodated Leichhardt's tall frame and possessions (Figure 4). The camp was probably not far from a sawyers' hut; camping at the base of the mountain allowed him to climb to the top of the mountain on a number of occasions to collect plants and contemplate nature.

In a long letter to Robert Lynd written later at Glendon on 19 February 1843 he wrote "The man returned to Glendon to fetch provisions, so I lodged myself in a hollow black butt tree in which I could just extend the full length of my body. I took the long leaves of the fern tree and spread them over the floor and over the walls of my lodgings. A cheerful fire was burning before it. So I lived alone, accompanied only by my dog for four days, making excursions to the different parts of the mountain. For Breakfast, Dinner and Supper I had my tea and suggar, damper and bacon. Before sunset I ascended frequently Piri, from the top of which I enjoyed the most beautiful view over the distant mountain Ranges, which have very generally a direction from North to South. This view is not so grand as that from Mt Royal, which is above all description magnificent, laying this mountainous country like a map before your feet, with all the valleys and creeks or brooks which rise from its flancs. Fallbrook from the west, Carrocreek or Busby creek from the East, the Paterson and Allan River from the North or North East. At nightfall I descended to my hollow tree prepared my tea, wrapt myself in my blanket and watched Orion and Sirius gliding slowly through the foliage of the black butt. The flying squirrel commenced to call, the Wallabi came from the brush to browse on the rich grass of the forest and the mountains. I felt myself exceedingly happy, dreamt with open eyes, till the eyelids became heavy and the head sunk to the saddle which formed my pillow." (Aurousseau 1968 p633)

During his four days alone, with consistent south-easterly winds bringing partly cloudy and cool weather, he explored the ridge of Pieries Peak from south to north on foot, as well as the rainforest brushes. Herbarium specimens collected at Mt Royal and Piri are marked with dates from this period. He made many observations of plants and the landscape including sketches of the geology of the area (Figure 4). His herbarium specimens and Diary records show a particular interest in ferns and rainforest plants.

The weather in much of the Upper Hunter is typically much drier than at Mt Royal and the Maitland Mercury \& Hunter River General Advertiser of Sat 11 Feb 1843 noted "The atmosphere has been threatening for rain for some days, but none has fallen. The country from Murrurundi to Singleton is in a deplorable, parched up state, neither grass nor water; and to show the dryness of the season, Glennies Creek, that has always been full of water at the crossing place, near Johnstone's inn, has now ceased running; a circumstance the more remarkable as no person ever remembers seeing it so dry before, or void of a running stream." In contrast, there was still water in the springs and gullies of the mountains.

\section{Kurranulla Creek}

On 29 January Leichhardt returned to St Clair to track down his horse. "I had descended Piri and after I crossed a thick scrub, in which the tree-like lianas obstructed my way, so 
that I often had to clear it myself with knife and hammer, I came to a forest ravine, which lead down from Jump Up Hill to Carro Creek." (Darragh \& Fensham 2013 p149). On the left side of a brush" I found a large number of plants, which it is true I had already seen in other neighbouring localities, but which I would like to have collected together, which is why on passing them I wrote down short notes about them." (Darragh \& Fensham 2013 p147) His Diary includes detailed descriptions of various plants from here.

This third day alone he spent the night camped near a creek in a "ravine" flowing east from Jump Up Hill (now Kurranulla Creek). The ravine "was filled by pudding [conglomerate] and sandstone blocks, and trees were either driven down the river from the mountains and were piled up by floods or the storm winds had broken them down and they now lie across the ravine. They had pulled over the lianas that climb up on them and these stretch from one bank to the other like ropes, even if the original tree is already destroyed, as the lianas striving upwards had already twined around new trees again. However, it was so late and because the ravine widened somewhat and presented a dry rocky bed free from boulders, in the bottom of which beautiful water was found, I made my fire with the wood of the nettle tree and with the dry foliage of Acmena, with which the heat had amply covered the rocks. Here I consumed my last piece of bread with a piece of bacon and a pot of tea. The night was dark, the ravine banks high, their edges crowned with tall trees, while lower growing bushes descend to the bed and cover the banks. The blazing fire moderately illuminated this forest scene. Sirius seemed to me lower. The ground cricket incessantly sounded its simple call. The flying squirrel chattered, then a gust of wind, which rustled through the crowns of the tall trees and the dry fallen foliage, through which small quadrupeds and lizards moved rustling here and there. In the morning parrots raise their incessant noise, the cockatoo sweeps screeching over the highest crowns of the trees. If I had previously regarded it as impossible to be able to live solely on fat, such as bacon, I now found, because my bread had run out, that this was very easily done, provided you take only small quantities at the beginning, so as not to suddenly overfill the stomach." (Darragh \& Fensham 2013 p149)

Kurranulla Creek and its ravine is a Leichhardt location that can be readily recognised today. Its rocky pools and cascades flow into Carrow Brook in a sheltered rainforest with an open leafy forest floor. Upstream the creek narrows and flows through rock outcrops, a narrow band of rainforest

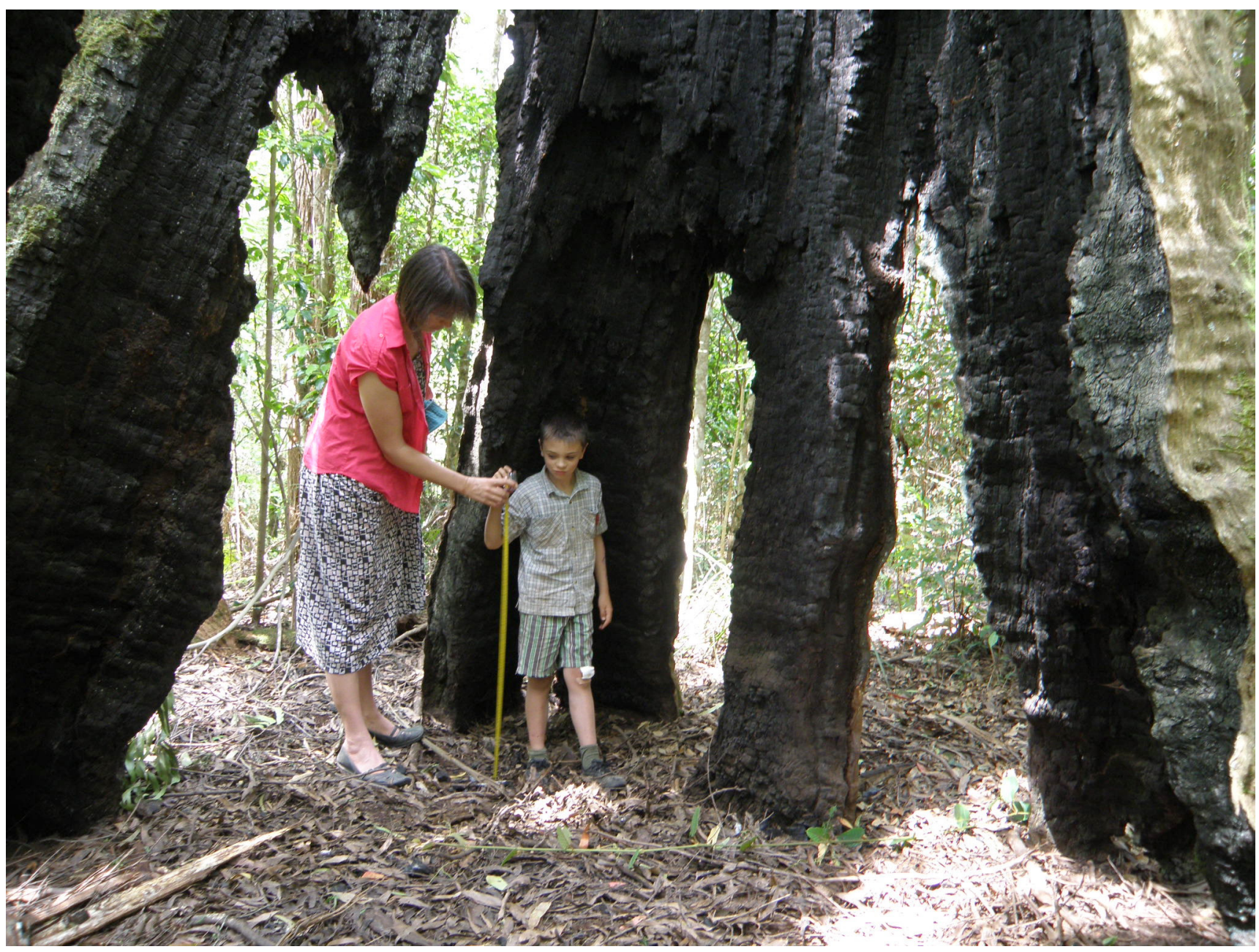

Fig. 3. Large dead hollow Eucalyptus tree near Pieries Peak, likely to be similar to the one Leichhardt described at his campsite in the area 


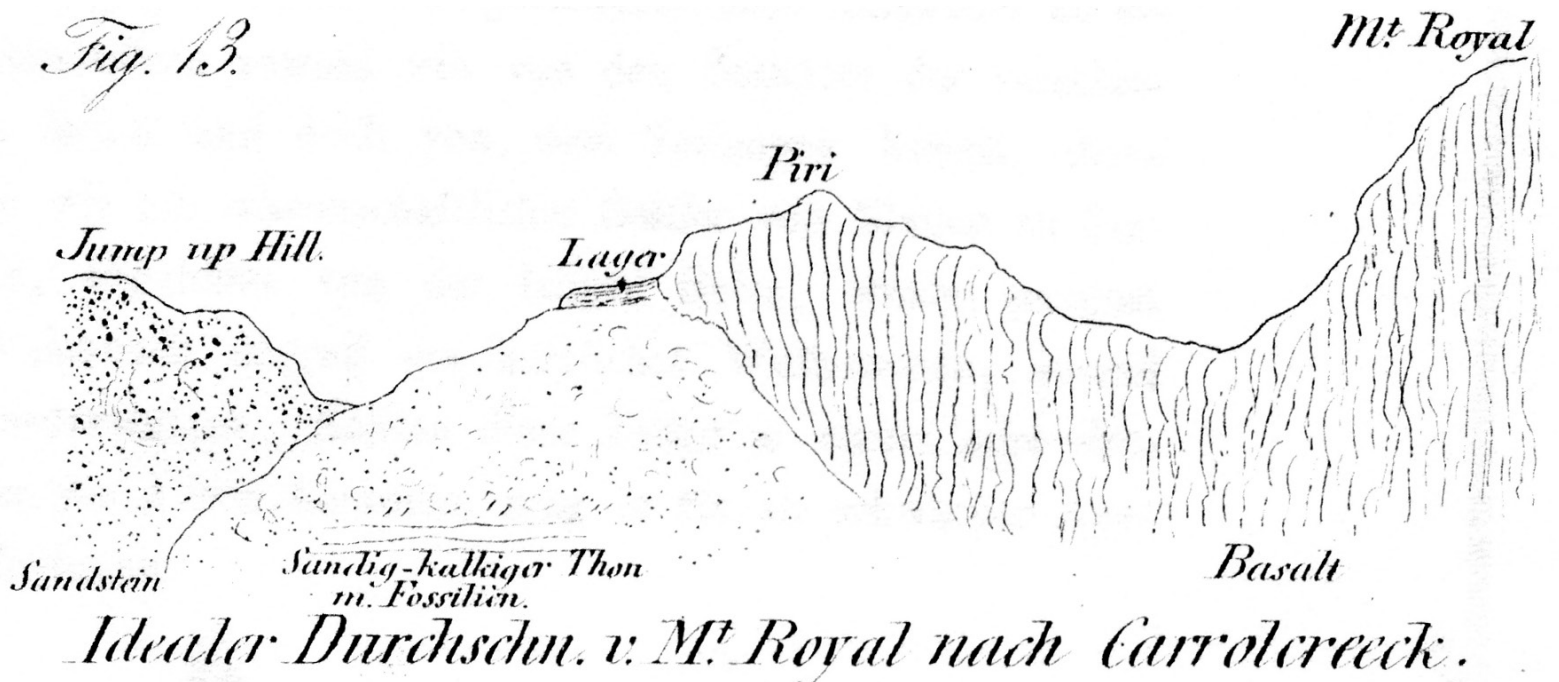

Fig. 4. Copy of Figure 13 from Leichhardt (1855) - Cross section from Jump up Hill to Mt Royal (note that this corresponds with Diary sketch 32 page 69). 'Lager' indicates his campsite below Pieries Peak.

through the tall eucalypt forest on either side. Leichhardt's descriptions of the landscape here are still applicable now, and plant species noted by Leichhardt in this creek still occur there.

On the afternoon of Monday 30 January he walked the 10 miles back to St Clair to stock up on provisions and to find his horse. "It had fought its way in some inexplicable manner to the valley and had joined Captain Mayne's mares there". (Darragh \& Fensham 2013 p153)

\section{Return to St Clair, Mt Royal revisited}

The next two days were wet and Leichhardt remained at St Clair writing up his Diary, exploring the vicinity of the homestead, and probably visiting the cliffs on Baybuck [Babock], a large and prominent hill overlooking St Clair. Following the return of the bullock dray from Glendon with provisions for him and the sawyers, he returned with his horse to his hollow tree at Pieries Peak. "Having returned

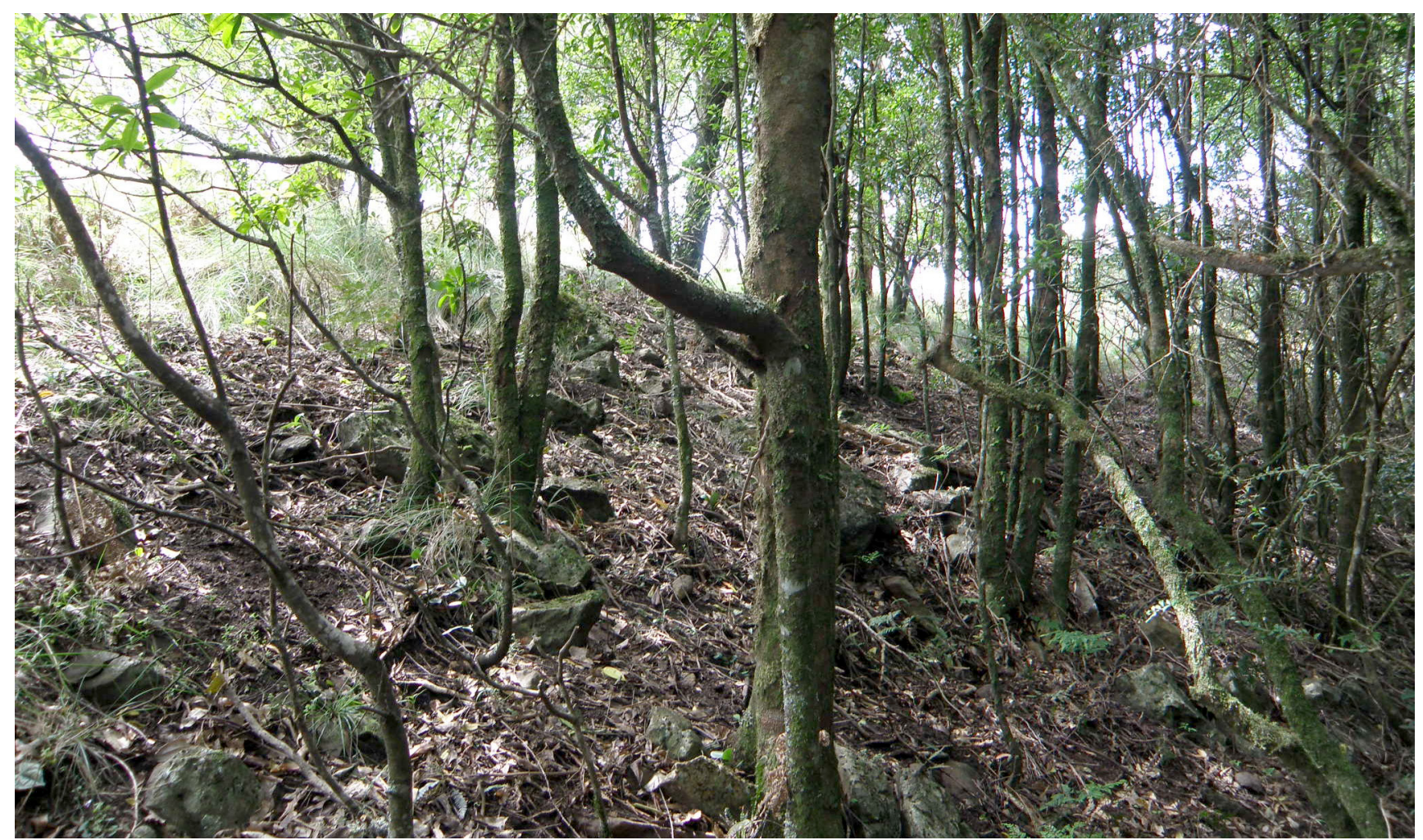

Fig. 5. Rainforest on Pieries Peak, eastern side 
to Piri, I began to collect and dry my plants, but I had to struggle with a good many difficulties. The trees in the brush are extremely tall, so it is almost impossible to identify leaves, stem and fruit if you are able to get the fruit and leaves at all." (Darragh \& Fensham 2013 p153).

In a letter to Robert Lynd written later from Glendon, he describes further difficulties "Mr Scott had sent me 5 quires of paper [folded papers for drying his pressed specimens] to collect plants for myself and for him and I wished to study the brush with leisure. But scarcely arrived at the mountain my horse went off a second time, I had to track it for 10 miles and to ride back without saddle and bridle (which latter I had forgotten in the hurry of the pursuit). As I was drying my paper the fire crept through a hollow branch up to it and destroyed not only 2 quires but also my shirt which I had just washed. At night the wind blew rather hard and carried one of the fern trees of my lodging, which were very dry, in the fire. The fire ran along it over to the tree to my blanket and at scarcely a moments notice I was all surrounded by the flame. As I was fortunately awake, I jumped up like lightning and threw blanket and everything from me." (Aurousseau 1968 p634)

His Diary gives more details. "During one night one of those large Alsophila [tree fern] leaves fell out of my tree into the fire. The fire ran along it into the tree and then the blanket and tree were on fire. Fortunately, I was awake and could protect myself from burning, by throwing everything from me and jumping out of my camp. Then only two quires of paper and a shirt were burnt and finally I lost my pencil. This probably could have discouraged a man. In addition, I had to wash, to cook, and to wait for my horse until the rain drove me into the hut of the sawyers, who took over that duty for me. However, I felt extremely happy and cheerful and now pulling rheumatic pains in the small of the back alarm me. Only the limited extent of my resources distressed me. Everywhere I felt (?) the scantiness of my resoures with the existing abundance. However, I brought down many an interesting object with me." (Darragh \& Fensham 2013 p153)

Rain continued the following day as did Leichhardt's frustrations. "To fill the cup of my misfortunes, I lost my pencil next day and could not put any notes down. Rain commenced, I was compelled to send my plants home half dry and in order not to loose them, I had to follow them about 4-5 days afterwards." he wrote to Robert Lynd (Aurousseau 1968 p634)

In the cloudy and showery weather that continued for the next few days he presumably spent more time walking and observing, while staying somewhere near Pieries Peak with the sawyers. However Leichhardt always remained positive later writing to Robert Lynd "Is this not enough to discourage a poor soul, with no friend and comforter near him? I took it however very cheerfully, except loosing of the pencil, for I knew that I had kind friends who would say afterwards 'thank heaven that you are safe now' and so I thought with Eneas 'Et haec meminisse juvabit [Virgil, Aeneid. It will be delightful to remember this one day]." (Aurousseau 1968 p634)

Leichhardt's Diary and letters are unclear about the length of his visit to Mt Royal, notwithstanding one of his letters describing it as about 3 weeks. He appears to have camped near Piri from 26 Jan to 30 Jan (5 days), and returned again from 2 February to 8 or10 February (6 or 8 days), about 2 weeks at Mt Royal overall, and about 20 days in the area. Appendix 2 shows Leichhardt's activities at Mt Royal in chronological order.

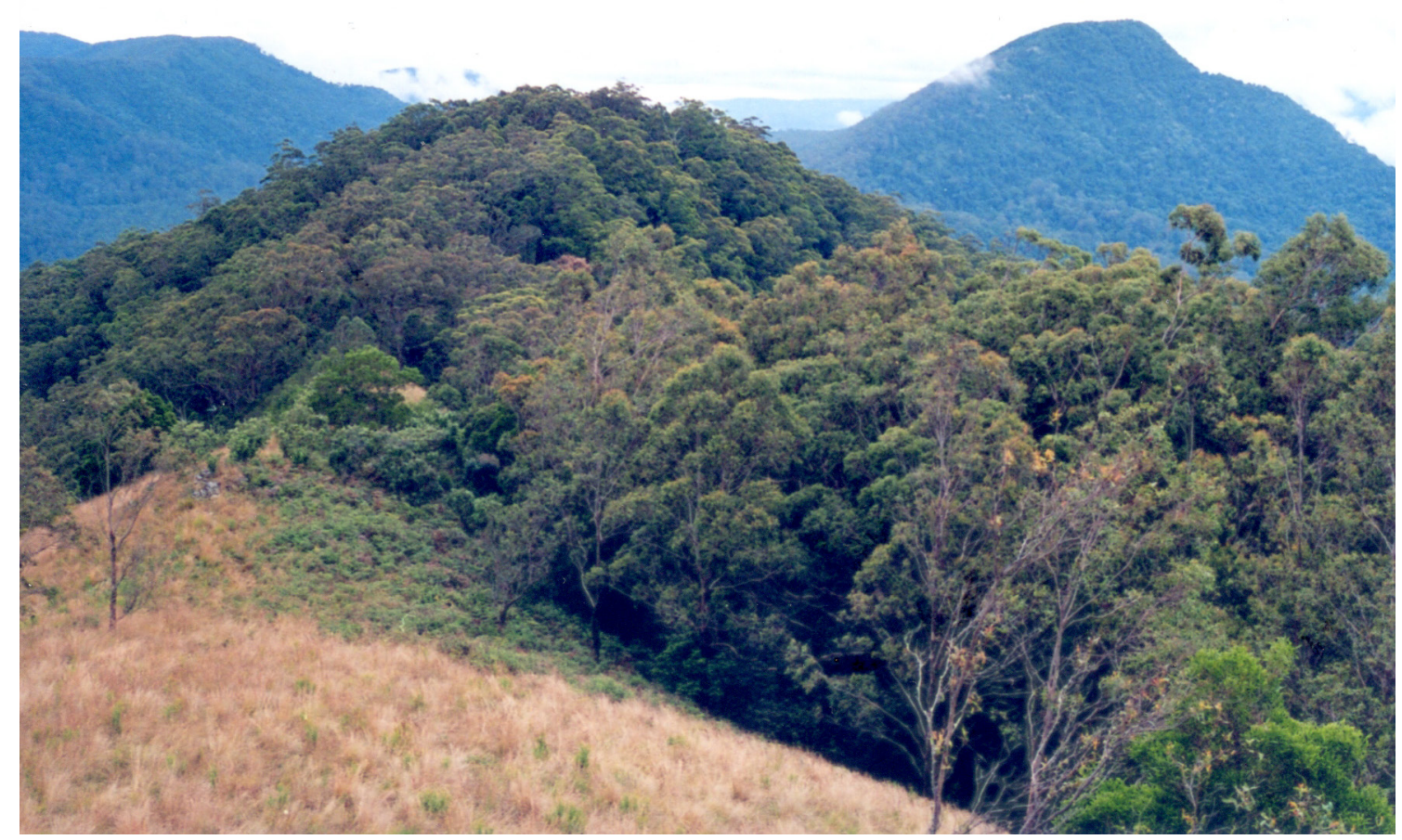

Fig. 6. Looking north to Mt Royal from Pieries Peak, showing grassland 'bald' in immediate foreground 
On 20 February 1843 Leichhardt reflected on his visit to Piri. "One evening as I went along on the highest ridge of Piri, an eagle passed over me in tranquil flight. It moved in circle upon circle around me. Finally it stopped right over me and now descended, probably to overcome me. The sun had set, but the sky was still light and clear, not a voice enlivened the stillness of the forest and mountain. I felt uneasy in the presence of this animal. I was not apprehensive, but could not bear this state of fearful suspense, so I put my stick against my cheek like a gun and puff the animal showed his fright in sudden quivering of his wings, which it immediately spread again to peacefully float further in the still air. It moved along the mountain, perhaps it was waiting for a wallaroo. Perhaps it had hunted the whole day in vain and was now very hungry. It returned again, circled around me again and finally left after a long sweep as the darkness became denser." (Darragh \& Fensham 2013 p155)

\section{Return to Glendon}

He returned to Glendon around 12 February where he stayed for about three weeks, attending to his plant specimens, writing letters, and adding to his Diary. Leichhardt's inquiring mind and attention to detail extended to observations of the grape picking and wine making at Glendon that European settlement had introduced.

In his letter dated 19 February to Robert Lynd he remarked "I shall still remain for some time in Glendon. I shall therefore expect your answer here. I am going afterwards to Dalkeith at the Liverpool Range. Mr Boydel has invited me to come to the Paterson, but I shall probably delay till I return. We have bushrangers here who have robbed several gentlemen, one of which Mr Hentig escaped very closely. The long rains have set in Friday last and they are very much required, for the grass which was so rich when I left for Mt Royal was all gone when I returned." (Aurousseau 1968 p635)

Weeks of wet weather and flooding followed, although it is difficult to gauge whether this was exceptional or normal summer weather at the time.

\section{The scientific results of the Mt Royal visit - Leichhardt's plant and animal collections}

An idea of the extent of Leichhardt's botanical knowledge, as well as the conditions under which he made his collections, comes through in his letters to Robert Lynd. For example "I have found a good number of fine plants, which will increase considerably our collection. I wished I could send you all I have now. A new asplenium, a new pteris some of the Norfolk island ferns. A number of little leguminous plants, some very pretty ones. Leaves and branches and sections of wood and some fruits of the brush trees for instance the red Sterculia. A fine Orchis with a pink flower was found at the hill before Piri. Some specimens are not well dried, but the greater number is tolerable." (Aurousseau 1968 p634)

The wet weather and occasional accidents with fires made the process of drying specimens difficult. Leichhardt mentions changing his plant collecting methods. "If many of my Newcastle specimens were bad, you must remember that I had to dry and to make excursions. I follow however

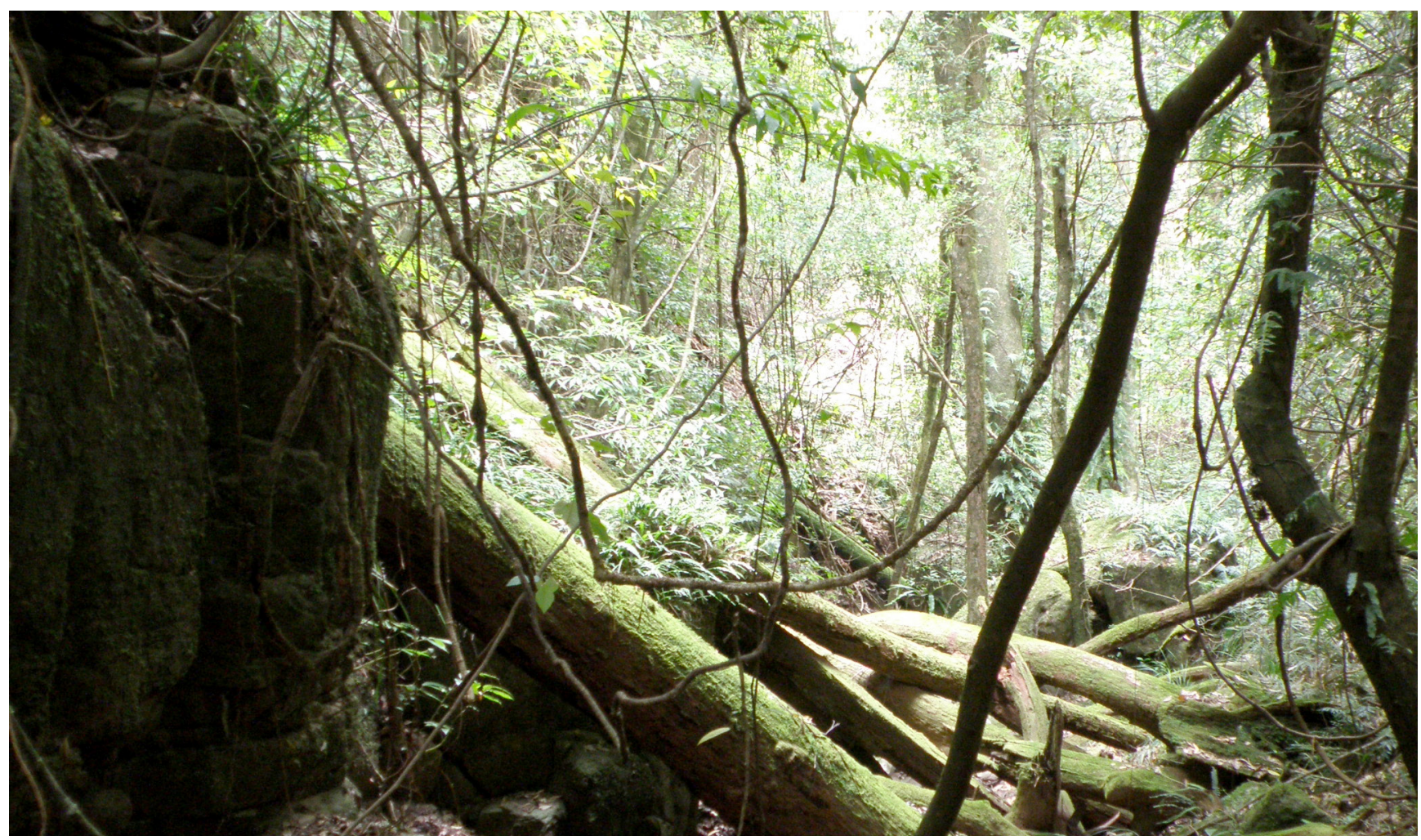

Fig. 7. Rainforest gully along Kurranulla Creek (ravine) 
Table 2 Leichhardt's plant collection locations at Mount Royal, January - February 1843 with extracts from his descriptions, plant specimens he collected or noted, and notes on the current (2013) landscape.

Location, map reference

\& 1843 landscape description

\author{
St Clair Station (Captain Maynes) \\ (Map ref 1) \\ Open grassland with garden areas and pasture
}

\begin{abstract}
Dyrinne (Map ref 2) (Mt Dyrring), endpoint of
\end{abstract} Bundock Range

"Valley of Fallbrook is bounded towards east and west by high mountain ranges. Generally of sandstone and pudding"\#. "Southern walls of pudding are covered by rich vegetation, and a large number of lichens and mosses. "You see a large number of strange mountain ranges, which I have tried in part to draw."

\section{Carro Creek (Near Map ref 3)}

(Carrow Brook), upstream of Captain Maynes

"Small grassy paddocks in which the silvertail especially and the red feathery oats were growing. Poa was abundant too. On the stream, Casuarina gives a pleasant dense shade whilst rare ironbark, box and appletree on the paddocks only provide moderate protection against the hot sun. Higher up, these paddocks discontinue after the upper ones had manifested many more ferns between the grass bushes and dense scrub (brush) formed by various rare trees took their place."

\section{Upper Carro Creek and Glennies Stockyard (South of Map ref 3)}

"In these creeks and mountain brushes magnificent cedars were found. Rosewood, mahogany and bluegum are also valued by the cutters who fell trees.

As you gradually descend to the valley and the valley floor widens, small grassy flats occur, here mostly covered with the silvertail, purple pinnate oats and a fine-leaved Poa. The various species of Eucalyptus occur in place of the brush plants, ironbark, stringybark, and spotted gum."

\author{
Specimens collected by Leichhardt \\ (source NSW or MEL) and species noted \\ in his fieldbooks or letters
}

Centipeda minima - Creek of Capt. Mayne's - MEL Gratiola peruviana - NSW

Geranium sp

Ottelia ovalifolia - NSW

*Sonchus oleraceus

*Sysimbrium $\mathrm{sp}$

Dendrobium speciosum

Pyrrosia rupestris

Rumex brownii - Rumex from Carro Creek - MEL

Angophora floribunda,

Dendrocnide excelsa,

Poa sp

Casuarina,

Brachychiton populneum

Ficus coronata

Polyscias sp

?Typhonium brownii or?Alocasia brisbanensis

Pteris sp

Asplenium $\mathrm{sp}$

Dictymia brownii,

Cheilanthes sieberi?

Lastreopsis or Polystichum

?Arachniodes aristata

identification of silvertail and red feathery oats uncertain

Scleranthus sp - Piri, Head of Carro Creek, the Hunter - MEL

Pimelea ligustrina - Pimelia brush of Piri and Carrow Creek, $r(t)$ ough bark MEL

Senecio bipinnatisectus - Carro creek - MEL

Senecio bipinnatisectus - NSW

Toona ciliata

Angophora floribunda

Casuarina cunninghamii

Persicaria sp

\section{Current landscape (2013)}

Now flooded by waters of Lake St Clair

Steep slopes and gullies with grassy forest. Used for cattle grazing
Open grassland and scattered trees due to past clearing and rainforest in sheltered gullies. Lower slopes have been inundated by the water of Lake St Clair
Open grassland and pasture with scattered trees. Some lower flats used for cultivation. Generally grazed. 
Location, map reference

\& 1843 landscape description

\section{Piri (Pieries Peak) (Map ref 4) \\ Piri forest}

The west side of the mountain is treeless "covered with the most beautiful grass".

\section{Piri brush (rainforest)}

Thick rainforest canopy, predominantly on eastern slopes.

"The easterly slopes of both mountains are covered with thick brush, in which the red cedar, a noble tree of 90 to 100 feet and more, the nettle tree with its broad, stinging leaves, and the tree fern are found - and they're all bound together by climbing plants and lianas, and covered with creeping and parasitic plants, and mosses and lichens."

\section{Jump Up Hill (unnamed but northern ridge is called Jump Spur) (Map ref 5)}

Jump Up Hill consists of sandstone, and is given its name on account of its steep northern slope.

\section{Forest ravine (Kurranulla Creek) (Map ref 6)}

Thick gully rainforest "in which the tree-like lianas obstructed my way, so that I often had to clear it myself with a knife and hammer, I came to a forest ravine, which lead down from Jump Up Hill to Carro Creek."

\section{Specimens collected by Leichhardt (source NSW or MEL) and species noted in his fieldbooks or letters}

Acacia filicifolia - The wattle from Piri forest-MEL Cheilanthes tenuifolia - Top of Piri-MEL Cyathea australis

Desmodium brachypodum -top of Piri Jan 43 - NSW Eucalyptus viminalis - Gums from piri forest Jan 43 NSW [Note this is probably E. nobilis)

Fimbristylis dichotoma - Top of Piri - MEL

Juncus continuous - Grasses from Piri - MEL

Opismenus hirtellus - Grass from the Top of Piri -

MEL

Platysace lanceolata - Trachymone Piri Forest - MEL

Pteridium esculentum - Pteris aquilina

Sambucus australiasica - Native Elder,

Forest of Piri-MEL

Senecio linearifolius var. arachnoideus - fennel

scented Senecio, forest of Piri Jan 43) - NSW

Acaena agnipila - MEL

Astrotricha tatifolia - MEL

Sub tropical to warm temperate rainforest on the eastern side of Blechnum patersonii subsp. patersonii - piri brush Jan Pieries Peak and in incised gullies. 1843 - NSW

Brachychiton acerifolius - Red Sterculia leaves and

red flowers Brush of Piri-MEL

Caldcluvia paniculosa-MEL

Cryptocarya glaucescens - MEL

Cryptocarya obovata - Piri Brush ... tree? - MEL

Callicoma. Small tree ${ }^{\wedge}-\mathrm{NSW}$

Orites excelsa - Small tree in the brush of Piri-MEL

Dendrobium pugioniforme brush of Piri-NSW

Diploglottis cunninghamii - leaf of a tree from Piri

brush Jan 43 - NSW

Doryphora sassafras - Sassafras tree in the brush of

Piri-MEL

Dysoxylum sp - Red Cedar leaffrom Piri brush - MEL

Elaeocarpus kirtonii-Brush of Piri-MEL

Elatostema reticulatum - Dorstenia from brush of Piri

- MEL

Elatostema reticulatum - Dorstenia? from piri brush

Jan 43) - NSW

Emmenosperma alphitonoides - MEL

Ficus coronata - Native fig from the brush of Piri-

MEL

Lomandra spicata - Xerotes from Piri brush - MEL

Rubus nebulosus - Piri Brush a vine - MEL

Urtica incisa - Nettle of Piri brush - MEL

Vesselowskya rubifolia - piri brush Jan 1843 together with Dorstenia grateola

Dipodium punctatum

Tall Eucalypt forest and grassy understorey. Previously heavily logged and partly cleared in private ownership.

Acmena smithi

Dendrocnide excelsa Nettle tree,

Dictymia brownii-Polypodium attached to trees and rocks in the brushes of Piri, Mt Royal, Carrocreek Jan 29, 1843 - NSW

Doryphora sassafras Sassafras,

Hedycarya angustifolia - NSW

" The ravine widened somewhat and presented a dry Marsdenia rostrata rocky bed free from boulders, in the bottom of which beautiful water was found."
Steep slopes with tall grassy forest Western slopes of Pieries Peak are treeless grassland. Within $\mathrm{Mt}$ Royal National Park.

Current landscape (2013)
Orites excelsus - NSW

Polyosma cunninghamii - NSW

Sambucus australasica - NSW

Identification of Ricinus, Rosewood, and cohiti wood uncertain 
Location, map reference \& 1843 landscape description

\section{Mt Royal (Map ref 7)}

The most magnificent view on the peak of Mt Royal repays all the effort of ascending. Mountain ranges, sharp ridged summits. The course of the waters is so surveyable and clear. It is a sea of hills and ridges, which vanish in the blue of the horizon. The Fallbrook and Carro Creek come from the rich brushes of the flanks (at least of the latter). A sharp ridge richly strewn with basalt rocks, which contain olivine, ilmenite and aragonite. Also at two thirds of the height a tendency to prism formation is found, but they are more irregular slabs. Also here, as on Piri, the eastern side is densely covered with rich scrub, whereas the western appears partly bare. The ridge becomes so sharp at the end that you have to clamber up over a wall of large granite blocks.

Whilst the lower part of the mountain is probably formed from massive basalt rocks, covered by a thin soil, the peak itself is formed from separated pieces of prisms often very regular, but heaped higgledy piggeldy over one another, between which much moisture is retained, which permits great assistance to the plant and tree life. So this rock wilderness is covered with a dense forest of bushes, undergrowth and low trees, between which the beautiful plants proliferate and especially large numbers of ferns. ...Arborescent climbing plants creep up on the trees and Polypodium and species of orchids with aerial roots cover the trunks. Long moss and lichen bundles hang down from the branches.

\section{Babock}

\section{(Baybuck Hill) (Map ref 8)}

The mountain with almost vertical southern rock walls

\section{Specimens collected by Leichhardt (source NSW or MEL) and species noted in his fieldbooks or letters}

Senecio bipinnatisecus - MEL

Lomandra longifolia labill. subsp longifolia - MEL

Carex dechinata - MEL

Lepidosperma leterale? - MEL

Notodanthonia longifolia - MEL

Sorghum leiocleolum? - MEL

Rubus rosifolius - MEL

Acaena novae-zelandiae - MEL

Rubus parvifolius - MEL

Acacia maideni - At the top of Mount Royal - MEL

Australopyrum pectinatum - MEL

Senecio hispidulus - pinnatifid senecio

Mt Royal - NSW

Pellaea nana poss LL Mount Royal

Dictymia brownii - NSW

Echinopogon ovatus - Mount Royal; Glendon - NSW

Cheilanthes sieberi Kunze subsp. sieberi-NSW

Themeda australis

Cyathea australis or leichhardtiana

Acacia melanoxylon

Hakea eriantha

? Notelaea longifolia or venosa

Astrotricha

?Cassinia compacta

Pellaea falcata var nana

Viola sp

Geranium sp

Desmodium brachypodum

?Lobelia serrata

?Epilobium undulatum

Cissus opaca - Vine from the south cliffs of Bebock Capt. Mayne's - MEL

Cayratia clematidea - Vine from the south cliffs of Bebock Capt. Mayne's - MEL

Clematicissus opaca - a vine from the southern cliffs of locations

Bibock near Capt Maynes Jan 29 1843-NSW

Dendrobium pugioniforme - NSW

?Platylobium, Bursaria, Correa reflexa, Dendrobium speciosum, Pyrrosia rupestris, Scaevola albida, Baeckea, Dendrobium speciosum, Pyrrosia rupestris, Kennedia rubicunda, Cheilanthes, Adiantum hispidulum, Adiantum formosum, Lomandra, Commelina cyanea

\section{Current landscape (2013)}

\begin{abstract}
Steep rocky slopes with dense forest. Tall grassy forest on western slopes and rainforest on south east. Some patches of treeless grassland near mountain top. Within Mt Royal National Park.
\end{abstract}

Steep, rocky slopes with cliffs. Grazed grassland with scattered trees and areas of grassy forest, and rainforest species in sheltered 
now a quite different plan - whenever time permits, I get my plants dry in 2-3 days, being all the time occupied with it. The collection of small specimens which you make is just the thing we want. It is very strange, that I did never find any of the Ophioglossumes an [d] Botrychin [..] The Gleichenias are quite wanting here about. [From margin: The description of the Mimosa which you [Robert Lynd] sent me, agrees exactly with the little plant here. I have it in fruit and blossom. It is very abundant. This district belongs perhaps to the flora of Pt Jackson.]" (Aurousseau 1968 p635)

The surviving specimens provide evidence of his collecting procedures. Some of the specimens still have small paper labels attached with locations in Leichhardt's handwriting e.g. gums from Piriforest on a Eucalyptus viminalis specimen or leaf of a tree from Piri brush Jan 43 on a Diploglottis cunninghamii specimen. These labels are written in ink and were presumably added when he worked over his material at Glendon or St Clair. In the field he used a pencil for recording. Examples of specimens from the Sydney Herbarium are shown in Figures 8-10.

About 108 plant species at Mt Royal can be linked to current botanical terminology through Leichhardt's writings and surviving herbarium collections including $22 \mathrm{Mt}$ Royal area specimens in the National Herbarium of NSW, 17 of which we sighted and photographed. The National Herbarium of Victoria (MEL) holds 40 specimens of Leichhardt's Mt Royal journey with six species common to the two herbaria. We have tabulated Leichhardt's plant collections from the Mount Royal area, his landscape descriptions, and the plant species he noted, together with a brief description of the current 2013 landscape (Table 2 Figures 5,6,7,11).

Although not primarily interested in documenting native fauna, Leichhardt referred to the native animals that he observed and their characteristics, including their culinary qualities. The species he noted (see Appendix 3) all still occur in the area today.

\section{Comparisons with the contemporary landscape}

Leichhardt's work at Mt Royal makes the area one of relatively few locations in Australia with comprehensive scientific documentation of plants and vegetation from the early nineteenth century. Yet despite these early records the first serious ecological work in the region was almost 100 years later in the classic ecological studies of the Barrington Tops approximately $20 \mathrm{~km}$ to the north east by Fraser \& Vickery (1937a,b, 1938,1939); there is no mention of any of Leichhardt's collections by Fraser \& Vickery although many species occur in both locations and vegetation descriptions are similar, as herbarium records were not available until specimens were databased after 2000.

Comparing Leichhardt's descriptions and specimens in the Mt Royal area with the same sites today provides historical evidence of the longevity of some of the major landscape and vegetation features existing today. Despite a history of logging and clearing as shown in Figure 1, substantial areas have remained relatively undisturbed and are now protected as National Park. Grassy mountain tops lacking trees and known as "grassy balds" are a feature of Mt Royal and Pieries Peak (Figures 6,11) and a small number of other peaks. The historical documentation suggests that these balds have changed little since first European settlement. Survey work in 1831 for Thomas Mitchell's map of 1834 described the summit of Mount Royal as being "alternately brushed and clear on summit" (Andrews 1992). Leichhardt's descriptions of Mt Royal in 1843 as covered with brush as well as patches of grassland confirms the earlier report as well as providing information on some of the plant species there at that time. The grassy balds at Pieries Peak noted by Leichhardt were later drawn on the 1883 portion plan, and show up on the earliest available aerial photography from 1939. These grassland mountain tops were identified as a notable botanical feature in Kinhill (1992).

Leichhardt's descriptions of the grassland of the valley at lower elevations (e.g. 'Carro Creek' entry in Table 2), seems to indicate that a more-or-less abrupt conjunction of rainforest with a grassy community (with only scattered hardwood trees) also occurred at valley floor altitude (and given the early date it may be inferrable that this was not simply a result of European clearing or grazing, although it might still be anthropogenic in a possible context of aboriginal burning). Unfortunately the valley floors are now denuded and altered by grazing, soil eutrophication and exotic pasture species that there are probably no remnants of such a conjunction of communities left.

That some minor landscape features observed by Leichhardt still exist today, is demonstrated by the existence of hollow trees similar to the one that provided his campsite (Figure 4). However even by Leichhardt's time European impacts were evident. Grazing by domestic stock appears to have been widespread on the lowland grassy areas perhaps for 20-30 years and Leichhardt notes some exotic plant species at least near areas of habitation. The incursions of the sawyers took them well up into the forests presumably targeting the valuable Red Cedar (Toona ciliata) but also cutting other species including Blue Gum. Leichhardt travelled with one sawyer who "worked for nine years in the Mount Royal brushes and there was no brush between the Hawkesbury and Port Stephens and the Liverpool Range that he did not know". (Darragh \& Fensham 2013 p150)

As a State Forest for many years Mt Royal has had a history of logging, but vegetation surveys of the Mt Royal area carried out for forestry purposes (Forestry Commission of NSW 1988; Shields, York \& Binns 1991) indicate the plant species Leichhardt observed still occur in the forests of Mt Royal National Park. Vegetation and species at some of Leichhardt's specific sites such as Pieries Peak and Kurranulla Creek (Table 2) indicate that there has been little major floristic change since Leichhardt's visit, though in contrast the landscape around St Clair has been completely inundated by the water of Lake St Clair and altered by grazing.

Finally the eagle Leichhardt watched on Pieries Peak was scared off by an imitation of shooting suggesting that firearms were already impacting the native fauna. 


\section{Leichhardt's legacy and the fate of his plant specimens}

The Mt Royal journey shows the 29 year old Leichhardt as a young collector early in his career. The characteristics shown became evident in his later journeys, including a quest for knowledge, attention to detail and accurate documentation, and persistence in the face of adversity. We have been surprised by the amount of detail he compiled for the relatively short Mt Royal section of his journey from Newcastle to Brisbane, and how much has survived in letters, the recently transcribed and translated Leichhardt diaries originally written in French, English and German in old script (Darragh \& Fensham 2013), and the high number of surviving plant specimens and their collection location details. The study of sections of the rest of this journey have potential to provide further insights into the natural history, especially of vegetation and plants in the early nineteenth century.

The subsequent history of the plant specimens collected by Leichhardt is not clear. His letters indicate he was sending them to Robert Lynd, and also to Scott. Some specimens were sent to Paris and Berlin (Tom Darragh to MPF pers com). According to Fensham et al. (2006) some of the surviving specimens from the Port Essington expedition in 1844 (many specimens had to be abandoned) were sent to Leichhardt's friend and botanical agent Gaetano Durando in Paris, and that Leichhardt requested that a set of duplicates be sent back to him in Australia. Fensham et al. suggest that this happened as some specimens are now held in herbaria in Sydney (NSW) and Melbourne (MEL).

Stephens (2007) indicates that after Lynd's departure from Sydney in late 1847, at least some of Leichhardt's rock and plant collections and fieldbooks were left for safekeeping with his landlord John Murphy (father of a member of Leichhardt's Port Essington expedition). After Leichhardt failed to return Murphy passed everything (including boxes containing specimens of natural history, books etc) over to the Australian Museum in 1853. Ferdinand von Mueller, colonial botanist in Melbourne asked to look at the plants early in the 1860s (Stephens 2007) and specimens were sent to him; it is not clear whether on loan or as a gift, but the National Herbarium of Victoria in Melbourne now holds over 2000 Leichhardt specimens. Some of these were evidently seen by George Bentham, and have presumably travelled to London and back.

In 1902 some Leichhardt plant specimens were discovered in the Australian Museum and these were transferred to the Herbarium at the Sydney Botanic Gardens (now the National Herbarium of NSW) (Stephens 2007). It is clear from the NSW Herbarium specimens that we have seen from Mount Royal, that some have been seen by von Mueller (his herbarium labels are attached (see Figure 9)), but others bear no such documentation and as there is not much duplication between the Mt Royal specimens held in Sydney and Melbourne (Table 2, Appendix 1), and may have come directly from the Australian Museum in 1902.

National Herbarium of NSW records (EMU) in Sydney indicate that of about 1000 Leichhardt specimens held there, at least 360 were collected in NSW (with about 100 from the Sydney area - including Symphionema paludosum his earliest surviving Australian collection), and the remainder, about 250, from the relatively little-known Newcastle to Brisbane journey. Of these 23 are from the Mt Royal area, and a further 20 from Glendon. Some specimens have no locality or dates but are consistent with these locations. Over 2000 specimens are held in Melbourne (MEL), including 1200 collected in NSW clearly from the same collecting trip. Of these 40 are from the Mt Royal excursion.

Dowe (2005) reviewed Leichhardt's collections from herbaria in Melbourne, Sydney, Berlin, British Museum, Edinburgh, Hobart, Kew, and Paris. He noted "The contribution made by Leichhardt toward the development of botany in Australia is acknowledged in a number of ways. Mueller, Bentham and others noted over 500 Leichhardt collections in works, about 2800 specimens have been located in herbaria, and at least 78 specimens have been designated as types. In relative terms this is a high proportion of types to numbers collected." One type specimen (Emmenosperma alphitonioides) was collected by Leichhardt from Piri Creek during the Mt Royal visit although the specimen has not been seen by us.

Overall we have been surprised to find that as many as 3500 of Leichhardt specimens survive in Australia (including about 1200 collected in NSW and 1500 in Queensland (and about 36 from Port Essington) as well as earlier collections he made in France and Italy (Table 3). Collections from other places are likely to have been sent to him by correspondents. The majority of his collections from NSW or south-east Queensland, probably represent the greater part of his collecting output from 1843-44, and while this paper concentrates on only a fragment of that collection, we hope it will generate interest in Leichhardt's work in NSW. To assist future research and in recognition of their historical value it is suggested that specimens at the National Herbarium of NSW might be put together as a special Leichhardt collection, like the Banks and Solander collection. At present the specimens are scattered throughout the main herbarium collection.

\section{Geology and landscape observations}

Leichhardt showed a keen interest in geology; Branagan (2012) notes his "fine geological background from two years of studying with the best French geologists" and his Diary includes landscape sketches and geological diagrams of Mt Royal (Figure 4). An overview of its geology was posthumously published in German in his Contributions to the Geology of Australia (Leichhardt 1855) though this publication appears to have been generally overlooked.

"On the way from Glendon to Mount Royal, a southerly extension of the Liverpool Range, which at its southern end appears as a cut off cone, one first goes through a large area of hills and ranges where one never sees distant views or an overview because it is consistently covered by forest. On several occasions porphyry breaks through the sandstones and even draws the attention of the general observer through the loose heaped sharp rocks. The Fallbrook valley is surrounded by higher mountains, and the conglomerate 


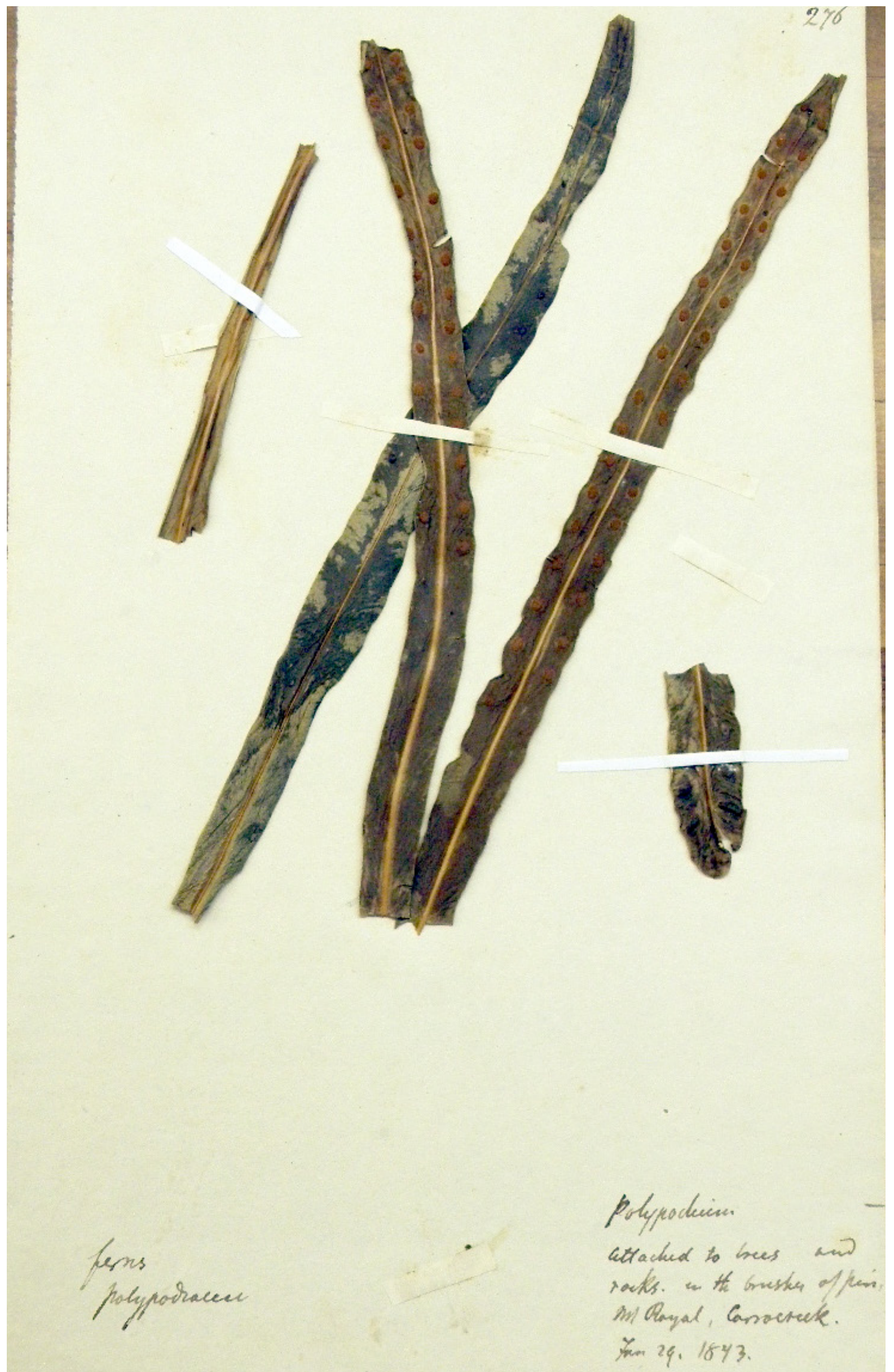

Fig. 8. Photographs of herbarium specimen of Dictymia brownii from Mt Royal, collected by Leichhardt. 


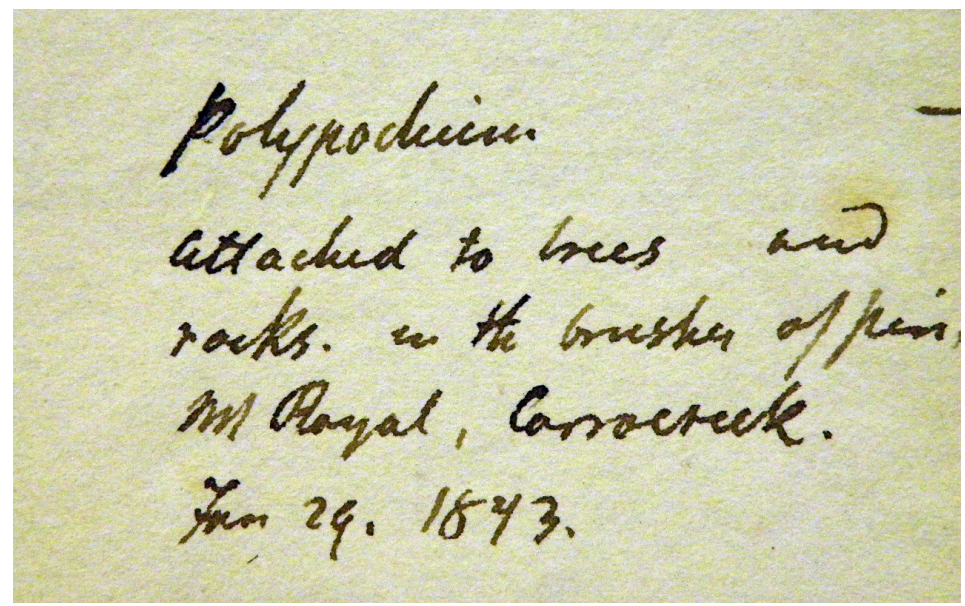

Fig. 9. Note in Leichhardt's handwriting

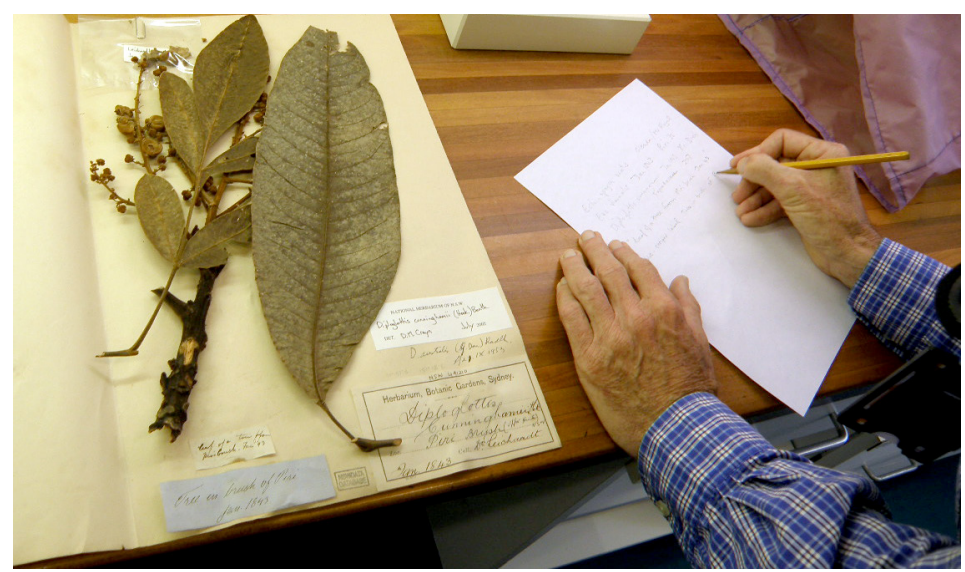

Fig. 10. Photographs of herbarium specimen of Diploglottis cunninghamii from Mt Royal

Table 3 Numbers of Leichhardt specimens by collecting locality held at the National Herbarium of NSW (NSW) and National Herbarium of Victoria (MEL).

According to T. Darragh (pers comm.) Leichhardt sent a significant number of specimens to Berlin (most were destroyed in a fire at the Berlin Herbarium during World War 2 except for a few ferns). There are a few specimens at Kew Garden in London probably sent by Mueller and 13 specimens at Brisbane, probably sent by Mueller, and possibly some at Das Naturhistorisches museum in Vienna (J Pattison pers comm.).

\section{Leichhardt's collection areas}

NSW

Qld

Northern Terr. (Port Essington)

Vict

South Aust

Tasmania

West Aust

Unknown locality but probably Aust.

France

Italy

New Zealand

total

\section{Sydney Herbarium (NSW)}

Melbourne Herb (MEL)

total

366

374

11

4

2

9

6

284

10

9

2

1077

$\begin{array}{ll}896 & 1262 \\ 1264 & 1638 \\ 25 & 36 \\ & 4 \\ & 2 \\ & 9 \\ 302 & 6 \\ & 586 \\ & 10 \\ & 9 \\ 2487 & 2 \\ & 3564\end{array}$


occurs everywhere. Mr Glennie has found coal at Fallbrook - between Mr Bundocks and Captain Maynes (St Clare) the syenite from Meranni is exposed several times, one can particularly observe this at the junction of two streams a short distance from Captain Mayne's. The floor of the valley and the low hills, on one of which the dwellings are built, are all composed of red conglomerate, while the higher mountains, Babock and Deren (Dyrring), comprise sandstone and conglomerate. Meranni (Mirannie) shows very similar characteristics. The same syenite can be found at the bottom of the mountain; higher up through the influence of heated rocks, is found conglomerate consisting of pebbles. Then there is a change not only in the sandstone and the syenite, but also a porphyry appears to have broken through these rocks. The summit is comprised of pudding which forms a low, vertical wall below the summit.

About 4 miles from St Clare upwards appear layers of a sandy and clayey limestone full of large (encrinite? fossil) stems, the largest 9 inches in size with a diameter of 1 inch, some of which are pressed together. The sandstone rocks lying on the grass show that this (encrinite) limestone lies directly under the sandstone.

This limestone occurs at Glennie's Stockyard and at the entrance of Carro Creek under Jump Up Hill where a fossil rich rock is exposed, which in its higher parts appears to look similar to slate. It is a sandy, lime comprising claystone.
One does not notice any mica platelets. Towards the top, one sees a lot of layers: often rhomboidal and jagged, these minerals being covered and penetrated by iron and pressed into rock. - About 150 feet higher the well known sandstone is observed again and comprises the long ridge which the hunters describe as Jump Up Hill because of its steep northern slope. As well as encrinites, one finds terebratulas, bivalves and univalves in these rocks. Also some plant materials were found. Here I believe I saw a trilobite. Although I could not find this small fossil again, so I would like to make later observers aware of this location. In general, the beds dip at 13 degrees to the east.

As one climbs up to the foot of Piri over several higher terraces (See Figs 11, 12, 13) [Figure 2C and Figure 4] are all comprised of sandstone, one notices the vigorous vegetation, the rich black soil, and the dark brown rocks, and that at last one has left the sandstone and is standing on a different formation, which one recognises as a hard, dark brown basalt with zeolite, peridot and titanium iron. This rock forms Piri, a long narrow undulating ridge, which lifts out of the sandstone like a thick wall. It goes from south to north and is connected to Mount Royal through a ridge with a few gaps that continues in the same direction, but which is significantly higher than Piri. Mount Royal as already described above, is connected to the Liverpool Range.

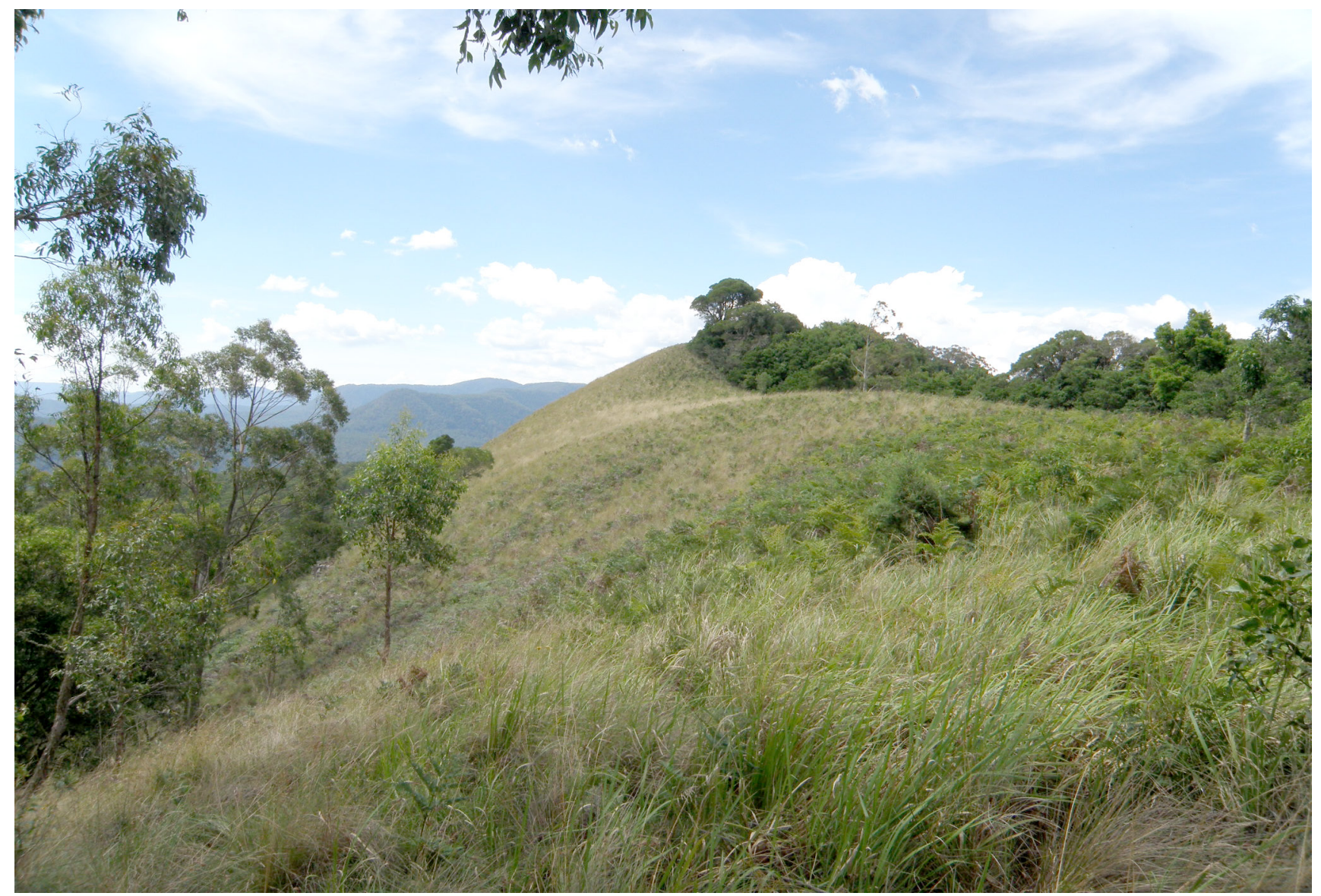

Fig. 11. Grassy bald on southern end of Pieries Peak near camp 
In a few locations, the highest ridge of Piri and the wider hilltop crest (ridge) of Mount Royal are so narrow that one has to climb these as if on a wall. On these, the rocks have a tendency to form columns. The columns are rather irregular blocks. While the lower part of the mountain is comprised of massive basalt rock covered by a thin layer of soil, the peak of Mount Royal is made of faulted, mostly regular shaped prismic blocks chaotically piled upon each other, which hold more moisture, and which promote the growth of plants and trees. So it is that this stone wilderness is covered with a thick forest of shrubs, undergrowth and low trees, between which lovely plants and particularly ferns flourish and proliferate. On the trees climb vines and polypodiums and orchid species with air roots covering the stems. From the branches hang moss and lichen. In the mornings the prevailing south easterly wind often leads to thick mist and rain, which naturally nourishes the eastern slopes, and is the reason why thick forest covers the eastern slopes of Piri and Mount Royal, whereas the dry west winds during the favourable season only allow a thick grassland on the western side." (Leichhardt 1855 p19, 20)

\section{Conclusion}

Our Leichhardt project shows that bringing together a reliable body of historical data for a particular location can provide insights and help interpret aspects of the contemporary landscape, and confirms the long term value of careful vegetation and landscape description and the collection and preservation of specimens.

Leichhardt's records of his weeks at Mt Royal culminated in an accurate description of the natural history of a relatively small area of NSW that provides evidence that despite substantial changes in some areas, sites at Mt Royal and Pieries Peak remain much as described 170 years ago. The historical record and the National Park protected lands together provide a base for evaluating future environmental change and management. There are probably few places in Australia as relatively unspoiled by post-European landscape change as Mt Royal, where the landscape was first documented reliably so long ago.

Other aspects of Leichhardt's excursion from Newcastle to Brisbane are not well-known, yet he left a lot of material in his (recently translated) Diary (Darragh \& Fensham 2013) and writings and a surprisingly large set of specimens from it have survived. It is surprising that such a large body of material has remained unknown, and it deserves serious study. As well as their scientific importance, the herbarium specimens have significant cultural and historical value and provide tangible links with two main driving forces in his life, botany and exploration. There is a strong case for connecting all Leichhardt's plant specimens together as one significant collection, in a global, virtual consolidation of images and other information sources.

Leichhardt was a well read, generalist natural historian with a wide range of scientific interests. He made an extensive contribution to understanding the botany, geology and zoology of NSW.
Leichhardt's visit to Mt Royal made a strong impression on him, and left him considering wider phytogeographic and ecological issues. A year later he reflected in a letter written in the Bunya Bunya district of southeast Queensland (to Gaetando Durando in Paris, 6 January 1844 translated from French). "I visited Mount Royal, one of the spurs of these mountains. It rises to about 3,000 feet $[1200 \mathrm{~m}]$ and is one of the highest mountains in that part of the colony. Mount Royal extends due south from New England on a straight line. Its heart and the conspicuous mass of it are basaltic but its flanks are formed of sandstone. Its eastern slope is covered with dense vegetation of quite an unusual character, called 'mountain brush' in the colony. To my mind, this brush, of which I happen to be making a special study just now, is the same thing as the virgin forests of South America. Waterton's fine description of it in his 'Wanderings in South America' applies quite aptly to the Mt. Royal brush, and even more to the Bunya Bunya mountain brushes. Within a small area you find a great variety of trees, thrusting up to a considerable height before branching, and bound together by just as great a variety of vines that have run right up to spread their leaves and flowers over the crowns of the trees. Herbaceous plants are only found on the margins of the brush, and in spaces open to the light and air. Ferns grow with particular luxuriance and in great variety; and in the little ravines at the base of the mountain, where a mixture of vegetable mould and decomposed basalt has accumulated, Alsophila grows to $15^{\prime}$ [5 m] in height and 10" [30 cm] in thickness. I've a satisfactory collection from these brushes but have not yet determined my plants as I have no books with me." (Aurousseau 1968)

Leichhardt's records of his time at Mt Royal provide a surprisingly personal picture of him as a scientist and bushman at an early stage in his career and provide an engaging story of what life was like on the edge of European settlement of Australia. His journey in a landscape then still new to science show his wide skills and interests and provides a legacy of observations on flora and fauna, geological descriptions, weather descriptions and on Aboriginal place names. The Mt Royal journey shows his quest for knowledge, exploration and accurate scientific documentation, together with the misadventures and persistence that were evident in his later explorations.

\section{Acknowledgements}

This work has been substantially assisted by the translation of the Diary by Tom Darragh, whose work in interpreting Leichhardt's handwriting and old German language in 5 diaries involved 4 years work from 2005 to about 2010. Tom also provided other assistance including details of Leichhardt specimens at the National Herbarium of Victoria (MEL) and elsewhere. Database information for National Herbarium of Victoria (MEL) specimens was provided under the Creative Commons (CC-BY) license as Royal Botanic Gardens Melbourne, MELISR database, 22 February 2013. The assistance of Dr. Josephine Milne, Manager Collections and Alison Vaughan Collections Information Officer is appreciated. 
Dirk Koenig reviewed the senior author's translation from German of the geology of Mt Royal in Leichhardt (1855). Max Elliott assisted in retracing Leichhardt's travels at Mt Royal, and with plant identification. Assistance from Ian Donovan and Graeme Hill in compiling historic map references and mapping is acknowledged. Comments on the manuscript from Tom Darragh, Jenny Pattison, Bob Makinson and Rod Fensham are gratefully acknowledged.

\section{References}

Andrews, A. E. J. (1992) Major Mitchell's Map 1834 - The Saga of the Survey of the Nineteen Counties. Blubber Head Press, Hobart.

Aurousseau, M. (1968) The Letters of F W Ludwig Leichhardt Volume II. Hakluyt Society, Cambridge.

Bailey, J. (2011) Into the Unknown. Macmillan.

Barker, R. M.; W. R., 'Botanical Contributions Overlooked: the Role and Recogition of Collectors, Horticulturalists, Explorers and Others in the Early Documentation of the Australian Flora', in Short, P.S. (ed.), History of Systematic Botany in Australasia: Proceedings of a Symposium Held at the University of Melbourne, 25-27 May 1988, Australian Systematic Botany Society, Melbourne, 1990, pp. 37-86.

Branagan, D. F. (2012) Fleshing out the Landscape: Two centuries of Australia's geological heroes, Episodes: Journal of International Geoscience 35(1): 44-56.

Bridgman, H. A. (1984) Climatic Atlas of the Hunter Region, University of Newcastle Board of Environmental Studies Research Paper No 9.

Darragh, T. \& Fensham, R. (2013) The Leichhardt diaries. Early travels in Australia during 1842-1844. Memoirs of the Queensland Museum - Culture. 7(1): i-x, 1-540.

Dowe, J. L. (2005) Ludwig Leichhardt's Australian plant collections 1842-1847, Austrobaileya 7:151-163.

Erdos, R. (1967), Leichhardt, Friedrich Wilhelm Ludwig (18131848) Australian Dictionary of Biography, National Centre of Biography, Australian National University, http://adb.anu. edu.au/biography/leichhardt-friedrich-wilhelm-ludwig-2347/ text3063, accessed 2 February 2013
Fensham, R. J., Bean A. R., Dowe J. L., \& Dunlop C. R. (2006) This disastrous event staggered me: Reconstructing the botany of Ludwig Leichhardt on the expedition from Moreton Bay to Port Essington, 1844-45. Cunninghamia 9(4): 451-506.

Finger, H. W. (2013) Ludwig Leichhardt: Lost in the Outback, translated by Kylie Crane, Rosenberg Publishing, Kenthurst.

Forestry Commission of NSW (1988) Management Plan for the Mount Royal Management Area, Forestry Commission of NSW.

Fraser, L. \& Vickery, J.W. (1937a) The ecology of the Upper Williams River and Barrington Tops districts. I. Introduction. Proceedings of the Linnean Society of NSW 62: 269-283. http://biostor.org/reference/67925

Fraser, L. \& Vickery, J.W. (1937b) Notes on some species occurring in the Upper Williams River and Barrington Tops districts, with descriptions of two new species and two new varieties. Proceedings of the Linnean Society of NSW 62: 284-293. http://biostor.org/reference/67926

Fraser, L. \& Vickery, J.W. (1938) The ecology of the Upper Williams River and Barrington Tops districts. II. The rainforest formations. Proceedings of the Linnean Society of NSW 63: 139-184. http://biostor.org/reference/67927

Fraser, L. \& Vickery, J.W. (1939) The ecology of the Upper Williams River and Barrington Tops districts. III. The eucalypt forests, and general discussion. Proceedings of the Linnean Society of NSW 64: 1-33.

Leichhardt, F.W.L. (1855) Beiträge zur Geologie von Australien. H. Girard, HW Schmidt, Halle, Germany.

Kinhill Engineers Pty Ltd (1992) Proposed Forestry Operations in the Mount Royal Management Area: Environmental Impact Statement, Prepared for Forestry Commission of NSW.

Leichhardt, L. (1843) Diary January 16 to March 7, 1843. Mitchell Library, Sydney ML MSS 683.

Mitchell, T. (1834) Map of the Colony of New South Wales.

Röpert, D. (Ed.) 2000 - (continuously updated): Digital specimen images at the Herbarium Berolinense. - Published on the Internet http://ww2.bgbm.org/herbarium

Scott, A. W. (1864) Australian Lepidoptera and their transformations drawn from the life. J. van Voorst, London.

Shields J M, York A \& Binns D, (1991) Flora and fauna survey, Mt Royal Management Area, Newcastle region. Forest Resources Series No. 16. Forestry Commission of NSW.

Stephens, M. (2007) From lost property to explorer's relics: The rediscovery of the personal library of Ludwig Leichhardt. Historical Records of Australian Science 18: 191-227.

Manuscript accepted 10 September 2013 


\section{APPENDIX 1 Leichhardt's Mt Royal plant specimens held at the National Herbarium of NSW (NSW) and National Herbarium of Victoria (MEL), showing Herbarium accession numbers and Leichhardt's specimen notes}

Location/Species

Family

St Clair Station

Centipeda minima subsp. minima

Gratiola peruviana.

Asteraceae

Scrophulariaceae

MEL

NSW

2158212A Creek at Capt. Maynes

\section{Dyrinne}

Dendrobium pugioniforme

Orchidaceae

NSW

Thymelaeaceae

Polygonaceae

Caryophyllaceae

Asteraceae

Asteraceae

Senecio bipinnatisectus

Senecio bipinnatisectus

\section{Piri forest}

Oplismenus hirtellus

Cheilanthes tenuifolia

Fimbristylis dichotoma

Acaena agnipila

Desmodium brachypodum

Platysace lanceolata

Acacia irrorata subsp. irrorata

Sambucus australasica

Eucalyptus viminalis $\quad$ Myrtaceae
Senecio linearifolius var. arachnoideus Asteraceae

\section{Piri brush}

Astrotricha latifolia

Blechnum patersonii subsp. patersonii Blechnaceae

Brachychiton acerifolius

Brachychiton acerifolius

Caldcluvia paniculosa

Cryptocarya glaucescens

Cryptocarya obovata

Diploglottis cunninghamii

Doryphora sassafras

Dysoxylum

Elaeocarpus kirtonii

Elatostema reticulatum

Elatostema reticulatum

Emmenosperma alphitonioides

Lomandra spicata

Vesselowskya rubifolia

\section{Kurranulla Creek}

Dictymia brownii

Orites excelsus

Marsdenia rostrata

Sambucus australasica

Rubus nebulosus

Ficus coronata

Urtica incisa

Orites excelsus

Juncus continuus

\section{Mt Royal}

Acacia maidenii

Acaena novae-zelandiae

Australopyrum pectinatum

Carex declinata

Cheilanthes sieberi subsp. sieberi
Poaceae

Pteridaceae

Cyperaceae

Rosaceae

Fabaceae

Apiaceae

Fabaceae

Myrtaceae

Malvaceae

Malvaceae

Cunoniaceae

Lauraceae

Lauraceae

Sapindaceae

Atherospermataceae

Meliaceae

Elaeocarpaceae

Urticaceae

Urticaceae

Rhamnaceae

Asparagaceae

Polypodiaceae

NSW

633371

Proteaceae

Apocynaceae

Adoxaceae

Rosaceae

Moraceae

Urticaceae

Proteaceae

Juncaceae

\section{Fabaceae}

Rosaceae

Poaceae

Cyperaceae

Adiantaceae

MEL

MEL

MEL

MEL

NSW

MEL

MEL

MEL

NSW

NSW

MEL

MEL

MEL

MEL

MEL

MEL

NSW

MEL

MEL

MEL

NSW

MEL

MEL

NSW

NSW

NSW

NSW

MEL

MEL

MEL

MEL

MEL
MEL

MEL

MEL

MEL

NSW
Caprifoliaceae

Cunoniaceae
2227445A Mount Royal

0626893A Mount Royal

2196656A Mount Royal

$192596 \quad$ Mount Royal
0580326A Mount Royal
MEL

MEL

MEL

MEL

NSW

$\begin{array}{ll}\text { 2137446A } & \text { top of Piri } \\ \text { 2152003A } & \text { top of Piri } \\ \text { 2202787A } & \text { top of Piri } \\ \text { 0021829A } & \text { top of Piri } \\ \text { 105325 } & \text { top of Piri Jan } 43 \\ \text { 2253216B } & \text { Piri Forest } \\ \text { 0015520B } & \text { Piri forest } \\ \text { 1595210A } & \text { Forest of Piri } \\ 318683 & \text { Gums from piri forest Jan } 43 \\ 117916 & \text { fennel scented Senecio, forest of Piri Jan } 43\end{array}$

2248276A Brush of Piri

294108 piri brush Jan 1843

0070010A Glendon. Brush of Piri

0070011A brush of Piri

0262703A brush of Piri

0622984A brush of Piri

0623449A Piri brush, Glendon.

$491210 \quad$ leaf of a tree from Piri brush Jan 43

0003252A In the brush of Piri

0118688A Piri Brush

2226631A brush of Piri

0279920A brush of Piri

$430290 \quad$ Dorstenia from piri brush Jan 43

0713021A brush of Piri

2216017A From Piri brush.

140750 piri brush Jan 1843 together with Dorstenia grateola, Callicoma. Small tree

562536

662509

244528

0031350A Piri

1063175A Piri

2042122A Piri

2176646A Piri

2187432A Piri
Polypodium attached to trees and rocks in the brushes of Piri, Mt Royal, Carrocreek Jan 29, 1843

Jan 1843

Piri Brush

Piri

$i$

Piri 


\section{Location/Species}

Echinopogon ovatus

Hedycarya angustifolia

Lepidosperma laterale

Lomandra longifolia subsp. longifolia Asparagaceae

Lomandra longifolia subsp. longifolia Asparagaceae

Notodanthonia longifolia

Ottelia ovalifolia

Pellaea nana

Polyosma cunninghamii

Pseudognaphalium luteoalbum

Rubus parvifolius

Rubus rosifolius

Senecio hispidulus

Sorghum leiocladum

\section{Baybuck}

Cayratia clematidea

Clematicissus opaca

Cissus opaca
Family

Poaceae

Hydrocharitaceae

Adiantaceae

Escalloniaceae

Asteraceae

Rosaceae

Rosaceae

Asteraceae

Poaceae

Vitaceae

Vitaceae

Vitaceae
Herbarium Specimen Notes on specimen-likely to be Leichhardt's number

$\begin{array}{ll}\text { 544464 } & \text { Mount Royal; Glendon } \\ \text { 67829 } & \\ \text { 2202853A } & \text { Mount Royal } \\ \text { 0025147A } & \text { Mount Royal } \\ \text { 0025164A } & \text { Mount Royal } \\ \text { 2136159A } & \text { Mount Royal } \\ \text { 3447 } & \text { Mt Royal, Glendon } \\ \text { 593555 } & \text { Mount Royal } \\ \text { 628690 } & \text { Brush of Piri, Jan 1843 } \\ \text { 685173 } & \text { Mount Royal } \\ \text { 0246927B } & \text { Mount Royal } \\ \text { 1058189A } & \text { Mount Royal } \\ \text { 66732 } & \text { pinnatifid Senecio Jan } 43 \\ \text { 1548069A } & \text { Mount Royal }\end{array}$

MEL

NSW

$2244532 \mathrm{~A}$

142499

South cliffs of Bebock

a vine from the southern cliffs of Bibock near Capt Maynes Jan 291843

MEL

2241635A From the South Cliffs of Bebock, Capt Maynes 


\section{APPENDIX 2 Chronology of Leichhardt's activities at Mt Royal and weather summary from 23 January to 25 February 1843}

During the period of Leichhardt's journey to Mt Royal he experienced dry (drought?) conditions which ended in cloudy and showery weather and heavy rains. The weather described in the Diary is confirmed in available newspaper reports. Note that Sydney weather conditions are indicative of broader regional weather patterns and can be used to indicate local weather in the Hunter Valley and at Mt Royal.

Weather reports sourced from the Sydney Morning Herald and Maitland Mercury, Australian National Library - Trove website - http://trove.nla.gov.au/ndp

Leichhardt's activities

Monday 23 January 1843

Attacked by wild bullock at Glendon. Loses geological hammer.

Tuesday 24 January 1843

Travel from Glendon to Captain Mayne's at St Clair.

Leichhardt's horse fell with him.

Wednesday 25 January 1843

Climbs Dyrrine

Thursday 26 January 1843

Left Captain Maynes for Piri. On reaching Piri, horse broke bridle and returned to Captain Maynes. Returns via Jump Up Hill and "makes tiring valley and mountain path a second time." Low on provisions.

Friday 27 January 1843

Leichhardt searches for horse but could not find it. Companion returns to Glendon to fetch provisions and Leichhardt camps in a hollow 'black butt' tree in grassland and spends 4 days alone accompanied by his dog. Frequently ascended Piri before sunset.

Saturday 28 January 1843

Day 2 alone. Near Piri. Probably climbed Mt Royal.

\section{Sunday 29 January 1843}

Day 3 alone. Camped near creek in ravine which lead down from Jump Up Hill to Carro Creek. Provisions ran out.

Monday 30 January 1843 (New moon)

Day 4 alone. Returns to Captain Mayne's at St Clair.

(herbarium specimen of this date)

Tuesday 31 January 1843

Captain Mayne's. Rainy day.

Wednesday 1 February 1843

Captain Mayne's. Rainy day. Probably visited Babock cliffs.

\section{Weather summary}

East/South Easterly winds along coast, dry with some cloud.

East/South Easterly winds along coast, dry with some cloud.

East/South Easterly winds along coast, dry with some cloud.

Light East/South Easterly winds along coast, dry with some cloud.

East/South Easterly winds along coast, dry with some cloud.

In Wollombi "There was every appearance of rain in the early part of the week, but none has yet fallen; the verdue consequently looks sickly, and the late maize shows signs of premature forwardness."

East/South Easterly winds along coast.

Wollombi - The Weather - There was every appearance of rain in the early part of the week, but none has yet fallen; the verdue consequently looks sickly, and the late maize shows signs of premature forwardness.

East/South Easterly winds along coast, partly cloudy with some light showers.

East/South Easterly winds along coast, partly cloudy with chance of showers.

Light drizzling rain in Singleton.

Strong East/South Easterly winds along coast, partly cloudy with light rain showers.

Moderate gusty East/South Easterly winds along coast, partly cloudy with showers. 


\section{Leichhardt's activities}

Thursday 2 February 1843

After 2 days of rain, during which he stayed at Captain Mayne's, the dray came up from Glendon with provisions. Leichhardt returned with his horse to his hollow tree at Piri. Soon after arriving, a horse went off a second time and Leichhardt had to track it for 10 miles and ride back without a saddle and bridle. Fire destroyed 2 quires of paper and his washed shirt.

Friday 3 February 1843

Lost pencil and could not write any notes. Rain commenced, and was compelled to send plants home half dry and in order not to lose them, had to follow them about 4-5 days afterwards. Letter notes that threat of rain constrained him to send plant collection back to Glendon by a bullock team that had just come up with provisions for the cedar getters.

Saturday 4 February 1843

Stayed in sawyers hut around this time for some days

Maitland Mercury reports that "there are two bushrangers between Singleton and Maitland, and that they have already robbed a traveller of his horse. Excepting this the district is quiet."

Sunday 5 February 1843

Monday 6 February 1843

Tuesday 7 February 1843

Wednesday 8 February 1843

Thursday 9 February 1843

Friday 10 February 1843

Saturday 11 February 1843

Maitland Mercury notes horrible outrage by Blacks at Glendon. Singleton - "The weather still continues dry; although last Thursday set in with

\section{Sunday 12 February 1843}

Leichhardt returns to Captain Maynes??

Monday 13 February 1843

Tuesday 14 February 1843 slight showers the afternoon was fair. We have had many cloudy days, and fully expected rain, but have not yet been blessed with any."

\section{Weather summary}

Cloudy with light rain.

East/South Easterly winds along coast, partly cloudy with occasional rain.

In Singleton "No rain has fallen here since the shower on the 9th of last month, except a little drizzling rain on Tuesday, the 31 st. As might be expected, the young corn is rapidly advancing to premature maturity; in some places where the ground was not properly worked previous to planting it has entirely failed. The grass which a few weeks past, had a cheerfully green appearance, is now withered and dry. This day (Thursday) has set in cloudy with occasional slight showers of rain."

Moderate East/South Easterly winds along coast, with low cloud and showers.

East/South Easterly winds along coast and high cloud. Some showers.

Strong westerly winds during day, shifting to south overnight along coast.

Cloudy with strong winds, humid.

Upper Hunter - "The atmosphere has been threatening for rain for some days, but none has fallen. The country from Murrurundi to Singleton is in a deplorable, parched up state, neither grass nor water; and to show the dryness of the season, Glennies Creek, that has always been full of water at the crossing place, near Johnstone's inn, has now ceased running; a circumstance the more remarkable as no person ever remembers seeing it so dry before, or void of a running stream."

Cloudy with south easterly breezes.

Light easterly winds along coast. Mostly clear with high cloud.

Cloudy with light showers in Singleton, afternoon fine.

Light easterly winds along coast.

Light easterly winds along coast.

In Singleton "The weather still continues dry; although last Thursday set in with slight showers the afternoon was fair. We have had many cloudy days, and fully expected rain, but have not yet been blessed with any."

Cloudy with light easterly winds along coast

Scattered cloud with light easterly breeze.

\section{Westerly winds}

Westerly winds, changing to South Easterly.

In Singleton, "Tuesday, the 14th, set in calm, and oppressively warm; in a hot breath of air, was felt, all was still and silent as death, until between two and three o'clock, when the wind suddenly commenced blowing with great force from the southward, bringing with it immense clouds of dust, and towards evening a little rain." 


\section{Leichhardt's activities}

Wednesday 15 February 1843 (Full moon)

Thursday 16 February 1843

\section{Friday 17 February 1843}

Leichhardt at Glendon again. "Long rains" have set in.

Saturday 18 February 1843

Begins to press wine at Glendon

Maitland Mercury reports that "The country between Maitland and Singleton has during the last week been in a state of excitement and alarm, in consequence of the many depredations which have been committed by bushrangers, at various places on the road."

Sunday 19 February 1843

Monday 20 February 1843

Tuesday 21 February 1843

Describes attractive 18 year old woman at Captain Maynes who "would make a very desirable spouse and house wife".

Wednesday 22 February 1843

Thursday 23 February 1843

Friday 24 February 1843

Meteor in Sydney noted

Saturday 25 February 1843

Maitland Mercury reports fight amongst the Aborigines - at Glendon

\section{Weather summary}

South easterly winds along coast.

In Singleton, "cloudy and cool, and a few slight showers fell".

In Singleton, "this day has also set in cloudy, with occasional slight showers of rain. Much of the late sown corn is completely destroyed, grass is scanty, and water becoming scarce."

Strong south easterly winds along coast.

East to north easterly winds. Cloudy with rain.

Easterly winds, cloudy with rain.

Singleton - The Weather - Tuesday, the 14th, set in calm, and oppressively warm; in a hot breath of air, was felt, all was still and silent as death, until between two and three o'clock, when the wind suddenly commenced blowing with great force from the southward, bringing with it immense clouds of dust, and towards evening a little rain. The following day was cloudy and cool, and a few slight showers fell; this day has also set in cloudy, with occasional slight showers of rain. Much of the late sown corn is completely destroyed, grass is scanty, and water becoming scarce. February 16.

Sydney rainfall 2.73 inches.

Strong easterly winds with heavy rain at times.

Sydney rainfall 3.55 inches.

Easterly winds with heavy rain at times.

Rain in Singleton. Heavy rain in Sydney with rainfall 2.01 inches.

Easterly winds with rain periods.

Rain in Singleton. Heavy rain in Sydney with rainfall 3.34 inches.

Easterly winds with rain.

Rain in Singleton. The River Hunter rose at Singleton on Wednesday about ten feet, but on Thursday morning the rain having in some degree abated it began to fall, and has gradually been decreasing.

Easterly winds along coast, some light rain.

In Singleton, "during the whole of the last week the rain has been almost unceasing, and from various parts of the country we learn that the overflowing of the creeks has done much mischief."

In Wollombi, "During the past week it has rained almost incessantly".

Light easterly winds, cloudless.

Light easterly winds, some thunderstorms.

The Floods - During the whole of the last week the rain has been almost unceasing, and from various parts of the country we learn that the overflowing of the creeks has done much mischief. The River Hunter rose at Singleton on Wednesday about ten feet, but on Thursday morning the rain having in some degree abated it began to fall, and has gradually been decreasing.

In Singleton, "The providential rains which have fallen during the last few days have again raised our hopes of a change for the better in our prospects. The last few months have offered little more to remark on than "Dry weather, and crops failing"; we trust to be able to make a more favourable report in future. Our chances for sown corn are now very good, and for winter feed the present rains are most favourable. The river is up, and bridges down, roads awful; but the cause is so much more valuable than the effect, in reference to those minor subjects, that they only remind us we must make roads and bridges which will not be affected by it." 


\section{Appendix 3 Fauna Species Noted By Leichhardt At Mt Royal}

\section{Species/ Location}

\section{MAMMALS \& MONOTREMES}

Rat/ Piri forest

Brush-tailed Phascogale?/ Piri forest

Greater Glider?/ In ravine

Wallaroo/ On Piri

Potoroo/ Carrow Brook

Wallabi/ On Piri

Platypus/ Carrow Brook

\section{BIRDS}

Bowerbird?/ St Clair Station

Raven/ St Clair Station

Magpies/ St Clair Station

Sulphur Crested Cockatoos/ St Clair

Station

Crimson rosellas?/ Forest ravine

Black or Glossy Black Cockatoo?/ Forest The cockatoo sweeps screeching over the highest crowns of the trees

ravine

Lyre bird/ Piri forest

Pied Currawong?/ Mt Royal

Brush Turkey/ Piri brush

Wedge tailed Eagle/ On Piri

\section{OTHER}

Flies/ Piri forest

Lizards/ Forest ravine \& Piri forest

Tiger snake?/ Piri forest

Spiders/ Piri forest

Other insects/ Piri forest

Crabs [presumably yabbies]/ Piri brush

Beetles/ Piri forest

Caterpillars/ Piri forest

Leeches/ Piri forest

Ticks/ Piri forest running hen

\section{Leichhardt's notes}

disturbed us particularly at night, which, however, I was never in a position to observe closely small black animal like a mouse with a foot for jumping and bushy tail, which lives on the trees. The flying squirrel chattered

As the sun sank, Wallaroos cam out of the thicket to graze on the beautiful grass

Consumed a Hypsiprymus with good appetite at the foot of the mountain. It tastes extremely tender if it is roasted quickly by a very hot fire. Tender, palatable flesh but requires some spices.

Ornithorhynchus lived in banks of the deep waterholes

\section{Mutton birds at St Clair station}

St Clair station

St Clair station

Next morning the wheat fields were covered with flocks of white cockatoos, which rose shrieking at the slightest suspicion and now withdrew like a mass of snow to the neighbouring Casuarinas and Angophoras

In the morning parrots raise their incessant noise

The lyrebird mimicked the call of other birds and the sawyers. Usually it is a simple call like that of a

One of the birds on the mountain frequently attracted attention. It usually called che a che a che aura. The native turkey is here as well.

One evening as I went along on the highest ridge of Piri, an eagle passed over me in tranquil flight

An extremely large white and black horse fly pestered the horse extremely and was probably the cause of its running away. Three pairs of white patches on the abdomen. Another horsefly with metallic brown abdomen was seen frequently. Blowflies and others flying numerously around me. A small kind of fly swarmed over the horse dung, red-headed with black apices on the wing.

Dry fallen foliage, through which small quadrupeds and lizards moved rustling here and there. A small lizard had taken possession of my hollow tree which my zoological curiosity compelled me to kill. It was very smooth with brown back and blackish flanks

Edwards had killed a 5' long snake, which showed bright yellowish transverse stripes on brownish ground colour

Spider with red feet and red thorax and black abdomen under the tree trunk

Cicadas. Also, I found a grey grasshopper with very long antennae

Crabs live in the damp ground.

A small white staphylium, just as a somewhat larger beetle which seemed to me to have short wing covers of yellowish colour. A small red beetle with black patches

I observed a geometer moth caterpillar. It is green, at the front and back pyramidal, fine black undulating longitudinal lines and spots on the back and venter. On the venter a white middle streak, fine similar ones with red spots on the respiratory holes on each side. It seemed to intend to imitate a twig, as it extended about 45 degrees from the tree

A crowd of insects in the decayed wood, small leeches with three yellow stripes over the back creep along it, when you go through the bush after the rain.

Ticks were ready to attach themselves almost to every animal from humans to insects. 